\title{
Convective initiation and maintenance processes of two back-building mesoscale convective systems leading to heavy precipitation events in Southern Italy during \\ HyMeX IOP 13
}

\author{
K.-O. Lee ${ }^{1 \dagger}$, C. Flamant ${ }^{1}$, V. Ducrocq ${ }^{2}$, F. Duffourg ${ }^{2}$, N. Fourrié2 S. Davolio $^{3}$ \\ ${ }^{1}$ LATMOS/IPSL, UPMC Univ. Paris 06, Sorbonne Universités, UVSQ, CNRS, Paris, France \\ ${ }^{2}$ CNRM-GAME, UMR 3589, Météo-France \& CNRS, Toulouse, France \\ ${ }^{3}$ Institute of Atmospheric Sciences and Climate (CNR-ISAC), Bologna, Italy
}

\begin{abstract}
During Intensive Observation Period 13 (15-16 October 2012) of the first Special Observing Period of the Hydrological cycle in the Mediterranean Experiment (HyMeX), Southern Italy (SI) was affected by two consecutive heavy precipitation events (HPEs). Both HPEs were associated with multi-cell V-sha ped retrograde regeneration mesoscale convective systems (MCSs). The life cycle of two MCSs in connection with their dynamic and thermodynamic environments were analysed using a combination of ground-based, airborne and spaceborne observations and numerical simulations. Rain gauges revealed that heavy precipitation occurred in two phases: the first one from 1300 to 1700 UTC (35 mm $\mathrm{h}^{-1}$ ) was caused by a V-shaped system initiating over the Tyrrhenian Sea in the early morning of 15 October. Convection was triggered by the low-level convergence between the south-westerlies ahead of an upper-level trough positioned over south-eastern France and very moist southerlies from the Strait of Sicily. The convection was favoured by high convective available potential energy (1500 $\left.\mathrm{J} \mathrm{kg}^{-1}\right)$ resulting from warm and moist conditions at low levels associated with high sea surface temperatures in the Sicily Channel. In addition, humidity at mid-level was enriched by the presence of an elevated moisture plume from tropical Africa, favouring the efficiency of the convection to produce more
\end{abstract}

\footnotetext{
$\dagger$ Corresponding author: email: keun-ok.lee@latmos.ipsl.fr
} 
precipitation. The second phase of heavy precipitation (2300 UTC on 15 October to 0200 UTC on 16 October, $34 \mathrm{~mm} \mathrm{~h}^{-1}$ ) was caused by a MCS initiating over Algeria around 1300 UTC, which subsequently traveled over the Strait of Sicily toward Sicily and SI. Convection was maintained by the combination of large low-level moisture contents and a marked convergence ahead of the cold front. Unlike other MCSs forming in the same region earlier on that day, this huge V-shaped system did affect SI because the strong upper-level flow progressively veered from southwesterly to south-southwesterly.

\section{Running title}

Upstream condition of deep convection over southern Italy

\section{Keywords}

airborne water vapour lidar, AROME-WMED analyses, SEVIRI, sea surface temperature, Tyrrhenian Sea

\section{Introduction}

The Western Mediterranean coastal regions are frequently affected by heavy precipitation events that produce flash floods and landslides (e.g. Ricard et al. 2012; Llasat et al. 2013). The continuous formation of convection in a specific area is one of the main factors responsible for high rainfall totals. Multicell V-shaped Mesoscale Convective Systems (MCSs) with retrograde regeneration have long been studied due to their capacity to produce heavy rain in a given location (Mc Cann, 1983; Scofield, 1985; Rivrain, 1997). These meteorological phenomena result from complex multi-scale interactions between the moist ambient inflow, topography and deep convection that makes forecasting the precise timing, location and amount of the precipitation a difficult task.

In the Western Mediterranean, synoptic-scale patterns associated with heavy precipitation events (HPEs) have been shown to be connected to upper-level troughs, responsible for generating low-level marine flow characterized by high values of equivalent potential temperature and precipitable water (Romero et al. 1999; Lin et al. 2001; Nuissier et al. 2008 and 2011; Ricard et al. 2012). Melani et al. 
(2013) also emphasized that both upper-level tropopause dynamical anomalies and low-level intense winds play a very important role in triggering convection in coastal mountainous areas and over the sea of the western Mediterranean. The coastal mountainous region (e.g. the Pyrenees, Massif central, Alps) favours convective initiation and HPE due to enhanced orographic forcing of warm and moist low-level marine flow (Rotunno and Ferretti, 2001; Rotunno and Houze, 2007; Nuissier et al. 2008, 2011; Trapero et al. 2013a and 2013b, Barthlott and Davolio, 2015); while the convective initiation over the sea is favoured by large-scale low-level convergence and flow modification around mountainous islands (e.g. Corsica, Sardinia, Balearic Islands) (Jansa et al. 2001; Cohuet et al. 2011; Barthlott et al. 2014; Romero et al. 2015). The low-level feeding flow to MCS is mostly from the south (or south-east) in southern France, but it is typically from the east or east-north-east in Spain (Catalonia, Valencia, the Balearics) and from the south-west or west in northern Italy, Corsica and Sardinia (Jansa et al. 2001; Romero et al. 1999; Nuissier et al. 2011). Jansa et al. (2001) found that about $90 \%$ of the HPEs in the Western Mediterranean involve the presence of a cyclonic centre in the vicinity, usually located so that it favours the creation and intensification of a moist low-level flow feeding the deep convection. The processes leading to moisture transport over the Mediterranean Sea are nevertheless quite diverse. Duffourg and Ducrocq (2013) estimated that evaporation from the Mediterranean accounts for only about $40 \%$ of the water vapour feeding the deep convection developed over the south-eastern France. The Atlantic Ocean (Winschall et al. 2012) and tropical Africa (Turato et al. 2004; Chazette et al. 2015b) have been also suggested as potential sources of moisture for HPEs in those regions.

In spite of these recent findings, the impact of the moist inflow on the timing and location of convective initiation is still poorly understood. It is also not clear that the importance of all the involved processes are well constrained. This is mainly because it is difficult to obtain relevant observations in the inflow region or within the convective storms, particularly over the sea.

The first Special Observation Period (SOP1, Ducrocq et al. 2014) of the Hydrological cycle in the Mediterranean Experiment (HyMeX, http://www.hymex.org/; Drobinski et al. 2014), took place in Autumn 2012 (from 5 September to 6 November). It aimed to improve our knowledge of the origin and transport pattern of moist air masses in pre-convective conditions and determine the link between these 
air masses and HPEs. During SOP1, dedicated ground-based, airborne and seaborne observing platforms were operated with the objective of documenting the connection between the moist flow over the Mediterranean and HPEs occurring over the coastal areas of Spain, France and Italy.

Our study focuses on two HPEs over southern Italy (SI) and the associated inflow from over the Tyrrhenian Sea. This is one of the preferential areas for deep convection development in fall (Melani et al. 2013) and these events occurred during the Intensive Observation Period 13 (IOP 13, 15-16 October 2012). During IOP 13, a cold front moved south-eastward from southern France to SI, and behind the cold front, mistral winds prevailed bringing cold and dry continental air over the sea. The mistral is frequently observed to extend as far as a few hundred kilometres from the coast and is one of the primary causes of storms over the Mediterranean (Jansa, 1987; Trigo et al. 1999; Campins et al. 2000; Drobinski et al. 2005; Di Girolamo et al. 2016). In the frontal region, the potential vorticity anomaly associated with the upper-level trough was responsible for the development of deep convection and intense rainfall over central Italy during IOP 13 (Barthlott and Davolio, 2015). In the early morning of 15 October, intense rainfalls $(60-80 \mathrm{~mm})$ was observed near the Liguria coast and in Tuscany (Fig. 1a). In the Liguria coast region, associated with the warm sector of the approaching frontal system, orographic blocking and uplift of low-level southerly flow triggered the development of heavy rainfall. Later on, a locally-generated low-level convergence in the lee of Corsica contributed to generate heavy rainfall in the Tuscany region (for details, see Barthlott and Davolio, 2015). Subsequently, as the cold front moved southward, SI experienced two periods of intense rainfall, peaking at 1700 UTC on 15 October (maximum rainfall intensity of $\left.34.8 \mathrm{~mm} \mathrm{~h}^{-1}\right)$, and at $0100 \mathrm{UTC}$ on 16 October $\left(33.8 \mathrm{~mm} \mathrm{~h}^{-1}\right)$. The MCSs developing over the Tyrrhenian Sea and the Strait of Sicily were successfully captured by ground-based, airborne and spaceborne observations. Furthermore, Rysman et al. (2015) reported that deep convection frequency during IOP 13 was between 2 to 4 times larger than the average for the period 2000-2013 and this period included particularly large MCSs travelling from Tunisia to Italy. Funatsu et al. (2009) also used spaceborne observations from the Advanced Microwave Sounding Unit radiometer to show the existence of an autumnal convective arc between Tunisia and SI during the period of 2001-2007. Even though these climatological analyses using the long-term satellite data have highlighted the high 
frequency of MCSs in this area upstream of SI, process oriented case studies allowing investigations of convective initiation and maintenance in connection with the dynamic and thermodynamic environment have not been conducted up to now.

The aim of the present study is to conduct such a detailed investigation using the wealth of data acquired off-shore and inland during IOP 13, together with analyses from the numerical weather prediction (NWP) model AROME-WMED (Application of Research to Operations at Mesoscale-West Mediterranean, Fourrié et al. 2015).

A detailed description of the dataset is presented in Section 2. Section 3 provides an overview of the two HPEs that occurred over SI during IOP 13 of the HyMeX SOP 1. Sections 4 and 5 detail the HPEs over SI during P1 and P2 respectively, including the life cycle of the MCSs and mesoscale environmental dynamics and thermodynamics. A summary and a discussion of the findings of the present study are given in Section 6.

\section{Observational and modelling dataset}

Unprecedented samplings of the dynamic and thermodynamic environment of HPEs in the western Mediterranean region was achieved during the HyMeX SOP1 (Ducrocq et al. 2014). More details concerning the observational datasets used in this study and the AROME-WMED analysis data are provided in the following.

\subsection{HyMeX SOP1 observational dataset}

\subsubsection{Existing and enhanced surface networks}

Hourly and 24-h accumulated rainfall (version V2) data over the HyMeX domain (western Mediterranean basin) were used, and the locations of the surface rain gauges over France and Italy used in this study are shown in Fig. 1. In addition, hourly surface station (SYNOP) data were employed to show the near-surface $(2 \mathrm{~m})$ temperature field. Data from radiosondes launched in Trapani (western Sicily, $12.3^{\circ} \mathrm{E}, 37.5^{\circ} \mathrm{N}$ ) were also exploited (see Fig. $1 \mathrm{~b}$ for location). Hourly horizontal distribution of total integrated water vapour (TIWV) content was derived from a network of global positioning system 
(GPS) stations (Bock et al. 2015). In addition, we used the half-hourly buoy measurements (www.coriolis.eu.org) of the sea surface temperature (SST) in the Strait of Sicily (around $11.5^{\circ} \mathrm{E}$, $37.5^{\circ} \mathrm{N}$; a star symbol in Fig. 1b). Finally, lightning data from the ZEUS system operated by the National Observatory of Athens was used to identify the most active convective clouds. ZEUS is a long-range lightning detection network (Kotroni and Lagouvardos, 2008) with receivers located at six sites over Europe (Birmingham in the UK, Roskilde in Denmark, Iasi in Romania, Larnaka in Cyprus, Mazagon in Spain, and Athens in Greece).

\subsubsection{Dedicated HyMeX SOP 1 airborne observations}

The LEANDRE 2 water vapour lidar on-board the SAFIRE (Service des Avions Français Instrumentés pour la Recherche en Environnement) ATR42 aircraft sampled the low-level moisture in the environment of the convective systems, which developed during the IOP 13 (ATR42 flight AS 49). The ATR42 flew back and forth between Bastia (Corsica, France) and Palermo (Sicily, Italy) from 0747 UTC to 1059 UTC on 15 October 2012. The LEANDRE 2 characteristics allowed measurements of the water vapour mixing ratio (WVMR) profiles with a precision ranging from less than $0.1 \mathrm{~g} \mathrm{~kg}^{-1}$ at 4.5 $\mathrm{km}$ above ground level to less than $0.4 \mathrm{~g} \mathrm{~kg}^{-1}$ near the surface (on average) for an along-beam resolution of $150 \mathrm{~m}$ (for the details, see Bruneau et al. 2001a and 2001b). During HyMeX SOP 1, WVMR profiles were measured with a horizontal resolution of $1 \mathrm{~km}$ (e.g. Chazette et al. 2015a, 2015b; Di Girolamo et al. 2016; Duffourg et al. 2016; Flamant et al. 2015; Flaounas et al. 2015).

\subsubsection{Spaceborne observations}

Calibrated thermal infrared brightness temperature (BT) data at $10.8 \mu \mathrm{m}$ and $6.2 \mu \mathrm{m}$, acquired every 5 min by the Spinning Enhanced Visible and Infrared Imager (SEVIRI) on-board the geostationary Meteosat Second Generation satellite (MSG, Bedka, 2011) were employed to investigate the evolution of deep convection. The spatial resolution of the MSG-SEVIRI data used is $0.05^{\circ}$ in both latitude and longitude. The deep convective systems leading to heavy precipitation in the SI domain were identified using SEVIRI BT at $10.8 \mu \mathrm{m}$ together with lightning activity. BT minima are generally indicative of 
the cloud top overshoots associated with deep convection (e.g. Kato, 2006; Bedka, 2011). As suggested by Kato (2006) a threshold value of $220 \mathrm{~K}$ was used in this analysis to identify deep convective cells, causing heavy precipitation. BTs at $6.2 \mu \mathrm{m}$ (the so-called water vapour channel) were utilised to characterize the distribution of moisture in the upper troposphere at the mesoscale. BTs higher than $-40^{\circ} \mathrm{C}$ (lower than $-50^{\circ} \mathrm{C}$ ) are generally considered as representative of dry (moist) upper-level air masses (Setvák et al. 2007; Bedka et al. 2009).

The National Oceanic and Atmospheric Administration (NOAA) oceansat-2 scatterometer (OSCAT, http://manati.star.nesdis.noaa.gov/products/OSCAT.php) ocean surface wind vector retrievals (level 2) at a spatial resolution of 25-km are employed to reveal the 10-m wind fields over the Western Mediterranean on 15 October. OSCAT overpassed the Western Mediterranean region twice on 15 October: around 1130 UTC during the descending-orbit (crossing $35^{\circ} \mathrm{N}$ at 1135 UTC) and around 2230 UTC during the ascending-orbit (crossing $35^{\circ} \mathrm{N}$ at $2230 \mathrm{UTC}$ ).

The moisture retrievals obtained from the Moderate Resolution Imaging Spectro-radiometer (MODIS) on-board the TERRA satellite were also employed (http://gdata1.sci.gsfc.nasa.gov/). The MODIS-derived TIWV contents and the partial integrated water vapour (PIWV) column between $700 \sim \mathrm{hPa}$ and $300 \mathrm{hPa}$ levels were analysed in order to describe the distribution of moisture at the synoptic scale during the events.

To investigate the impact of SST variability on the atmospheric moisture content and convective initiation, the Météo-France Centre for Satellite Meteorology multisensor SST analysis data were used. These data are obtained by an optimal interpolation of supercollated multi-sensor level 3 merged SST. The spatial resolution is $0.02^{\circ}$ in both latitude and longitude, and the temporal resolution is $3 \mathrm{~h}$. Observations from SEVIRI on MSG, MODIS on TERRA satellites, from the Advanced Very High Resolution Radiometer on the Meteorological Operational Satellite Program of Europe and the NOAA platforms as well as the Advanced Along-Track Scanning Radiometer on the Environmental Satellite were used to produce the SST analysis (Cailleau et al. 2012).

\subsection{The NWP model AROME-WMED}


To support the field campaign activities and to optimize flight planning during SOP1, a dedicated version of the operational convection permitting NWP model AROME was implemented (Fourrié et al. 2015). AROME-WMED is a regional non-hydrostatic, and fully-compressible and convection permitting model, covering the western Mediterranean basin with $2.5 \mathrm{~km}$ horizontal resolution and 60 vertical levels ranging from $10 \mathrm{~m}$ above ground to $1 \mathrm{hPa}$.

AROME-WMED implements the surface scheme (SURFEX; Masson et al. 2013) which diagnoses the $2 \mathrm{~m}$ temperature, $2 \mathrm{~m}$ humidity, and $10 \mathrm{~m}$ wind at every time step through a specific algorithm called surface boundary layer (Masson and Seity, 2009). Further model details can be found in Seity et al. (2011). The lateral boundary conditions are updated hourly and provided by the French operational global model Action de Recherche Petite Echelle Grande Echelle (ARPEGE, Courtier et al. 1991) forecasts.

With 3-h cycles, the initial atmospheric state of the AROME-WMED analyses is performed with the AROME data assimilation system (Brousseau et al 2008) which is derived from the regional Aire Limitée Adaptation Dynamique Développement International (ALADIN)-France 3D-Var scheme. At a $2.5 \mathrm{~km}$ horizontal resolution, AROME assimilates data from radiosondes, wind profilers, ships and buoys, surface stations (i.e. pressure, 2-m temperature and humidity, 10-m wind), GPS stations (i.e. TIWV), radars (i.e. radar-derived winds) and SEVIRI (i.e. infrared radiances) (Seity et al. 2011). Many important observing systems, such as SYNOPs, radar and SEVIRI data, are assimilated at a high frequency. An optimal interpolation scheme is conducted.

Fourrié et al. (2015) showed that the overall performances of the AROME-WMED were good for the HyMeX SOP1 (mean 2-m temperature root mean square error $(R M S E)$ of $\sim 1.7^{\circ} \mathrm{C}$ and mean 2m relative humidity $R M S E$ of $\sim 10 \%$ ) and similar to those of the AROME-France for the $0-30 \mathrm{~h}$ common forecast range (maximal absolute difference of the 2-m temperature $R M S E$ of $0.2^{\circ} \mathrm{C}$ and $\sim 0.2 \%$ for the 2-m relative humidity). Bock et al. (2015) highlighted a very good TIWV agreement between the AROME-WMED analyses products and GPS-observations, with a small wet bias in the models $(\sim 0.3$ $\mathrm{kg} \mathrm{m}^{-2}$ ) and a standard deviation of differences of $\sim 1.6 \mathrm{~kg} \mathrm{~m}^{-2}$. Chazette et al. (2015a) found good agreement between the TIWVs derived from AROME-WMED forecast and the Water vapour and 
Aerosol Lidar (WALI) during the entire SOP 1 (bias of $\sim 1 \mathrm{~kg} \mathrm{~m}^{-2}$ and $R M S E$ of $\sim 2 \mathrm{~kg} \mathrm{~m}^{-2}$ ). They also showed that the AROME-WMED forecast and WALI water vapour mixing ratio profiles in the lower troposphere (below $6 \mathrm{~km}$ amsl) exhibited biases less than $1 \mathrm{~g} \mathrm{~kg}^{-1}$.

In the present study, the AROME-WMED analyses data provided every 3 hours are used together with observations to enhance our understanding of processes responsible for HPEs in SI.

\section{HPEs over southern Italy}

During 15-16 October 2012 (IOP 13), the SI area (Fig. 1) was affected by two HPEs. At 1200 UTC on 15 October, an upper-level trough was located over south-eastern France, extending to northern Algeria (Fig. 2a). Later it moved eastwards towards Corsica. Ahead of the trough, at $500 \mathrm{hPa}$ levels, southwesterly winds stronger than $20 \mathrm{~m} \mathrm{~s}^{-1}$ prevailed over the Tyrrhenian Sea and SI. At lower levels (Fig. 2b), the cold front shifted over the Mediterranean Sea, and undulated around a low pressure centre situated close to the Gulf of Genoa at 1200 UTC. Behind the front, cold air was present at every level; ahead of the front, the flow was south-westerly and rather intense at every level. Details about the synoptic situation during this IOP can be found in Barthlott and Davolio (2015).

The temporal evolution of the maximum hourly rainfall recorded by the rain gauge network during IOP 13 in the SI domain is shown in Fig. 3. The first intense rainfall period (P1), defined as maximum precipitation exceeding of $10 \mathrm{~mm} \mathrm{~h}^{-1}$, occurred between $1300-1700 \mathrm{UTC}$ on 15 October (total precipitation of $62.4 \mathrm{~mm}$ ), and a maximum rainfall intensity of $34.8 \mathrm{~mm} \mathrm{~h}^{-1}$ was recorded between 1600-1700 UTC. The second intense rainfall period (P2) occurred from 2300 UTC on 15 October to 0200 UTC on 16 October (total precipitation of $75 \mathrm{~mm}$ ), with a maximum rainfall intensity of $33.8 \mathrm{~mm}$ $\mathrm{h}^{-1}$ between 0000-0100 UTC. During IOP 13, the highest GPS-derived TIWV values $\left(\sim 33.5 \mathrm{~kg} \mathrm{~m}^{-2}\right)$ were recorded by a station located at $15.8^{\circ} \mathrm{E}, 39.9^{\circ} \mathrm{N}$ at $0000 \mathrm{UTC}$ on 16 October. The hourly TIWV at this station (Fig. 3) shows that the TIWV values were continuously in excess of $25 \mathrm{~kg} \mathrm{~m}^{-2}$ from 1000 UTC, 15 October to 0300 UTC, 16 October.

The hourly evolution of the BT and lightning activity during P1, from 1300 UTC to 1600 UTC on 15 October, is shown in Fig. 4. During this period, the SI domain was affected by a V-shaped MCS 
(referred to as MCS A in the following) which has formed over the Tyrrhenian Sea. The MCS was initiated in the northern part of the Strait of Sicily around $11.5^{\circ} \mathrm{E} / 38^{\circ} \mathrm{N}$ at $0245 \mathrm{UTC}$ and developed into a V-shaped multi-cell retrograde regeneration convective system at around 0400 UTC (not shown). It then drifted north-eastward when it reached $12.5^{\circ} \mathrm{E} / 39^{\circ} \mathrm{N}$ at $1300 \mathrm{UTC}$. At the apex of the V-shaped MCS, the strongest convective cells were associated with a BT minimum of $208 \mathrm{~K}$ (cloud top height $\sim 13 \mathrm{~km}$ ) and strong lightning activity. Behind the overshooting cloud at the apex, a region of higher BT ( $\leq 220 \mathrm{~K}$, cloud top height $\sim 10 \mathrm{~km}$ ) extended north-eastward, from the area over the sea where new convective cells formed to the SI domain, with the mid-level south-westerly flow. Subsequently, from 1400 UTC to 1600 UTC (Fig. 4b-d), the convective part of MCS A (as diagnosed from lightning activity) and its anvil (characterized by BT $\leq 220 \mathrm{~K}$ ) moved north-eastward, over the SI area. At $1600 \mathrm{UTC}$, a core of lightning activity was observed inland, close to the coast indicating intense convective cells over the SI domain, responsible for heavy precipitation as shown in Fig. 3. After 1800 UTC, the low BT region progressively disappeared (not shown).

The hourly evolution of the BT and lightning activity from 2200 UTC to 0100 UTC during P2 is shown in Fig. 5. At 2200 UTC (Fig. 5a), a huge V-shaped MCS cluster (referred to as MCS B in the following) was observed over Sicily. The most intense convection was observed at the apex of the MCS over southern Sicily and was characterized by very-low BT values ( $202 \mathrm{~K}$, cloud top height $\sim 14 \mathrm{~km}$ ) and strong lightning activity. Leeward of this minimum BT region, warmer cloud with BTs of 210-220 $\mathrm{K}$ (cloud top height $\sim 13 \mathrm{~km}$ ) covered a large domain $\left(12-17^{\circ} \mathrm{E} / 36^{-}-40.5^{\circ} \mathrm{N}\right)$, extending north-eastward from the convective core, towards SI with the mid-level south-westerly flow.

The storm initiated over elevated terrain in the region of Batna (Algeria) around 1330 UTC (Fig. 4b-d). Orographic forcing associated with the highest summit in that region (i.e. Djebel Chélia, peaking at $2328 \mathrm{~m}$ amsl) likely was the cause of convective initiation. Two other convective systems formed close to Tunisia before MCS B but they did not affect the SI region. MCS I developed offshore of Tunisia at 0600 UTC (visible at 0930 UTC in Fig. 6) and MCS II over Tunisia at 1000 UTC (visible at 1300 UTC in Fig. 4a). Both MCSs dissipated before reaching continental Italy. Unlike MCS I and MCS II, MCS B was guided toward SI as the strong flow ahead of the trough progressively veered from 
southwesterly to south-south-westerly.

At 2300 UTC (Fig. 5b), the most active part of the MCS B (BTs $\leq 210 \mathrm{~K}$ and lightning activity) was observed over the southern part of Sicily (near $15^{\circ} \mathrm{E} / 37^{\circ} \mathrm{N}$ ). The large MCS anvil (characterized by BT values less than $220 \mathrm{~K}$ ) extended northward, reaching the SI area. Later, MCS B travelled northeastward with a convective core positioned over the Strait of Messina (between Sicily and continental Italy) at 0000 UTC on 16 October (Fig. 5c), and over Calabria at 0100 UTC (Fig. 5d), thereby approaching the SI area. This period corresponds with the time during which intense hourly-rainfall was recorded by rain gauges (Fig. 3). The most active part of MCS B was located over the southern part of Sicily. Hence, during P2, the observed rainfall is likely related to the stratiform part of MCS B rather than its convective core. It could also be related to orography-forced convection as the south-westerly flow ahead of the front impinges on the SI orography. Due to MCS B's widespread anvil and the lack of adequate instrumentation (i.e. radars), neither the convectively-forced convection nor the stratiform clouds associated with MCS B could be observed. It is therefore not clear what fraction of rainfall during $\mathrm{P} 2$ is provided by each of the two processes described above.

After 0300 UTC, $10.8 \mu \mathrm{m}$ BTs less than $220 \mathrm{~K}$ were scarce over SI in the SEVIRI imagery (not shown) as severe weather moved north-eastward.

\section{Environmental characteristics of MCS A}

\subsection{Observations}

The OSCAT-retrieved surface wind field (Fig. 4a) shows three distinct regions with different wind components during P1: 1) a region with north-westerly mistral winds $\left(\geq 10 \mathrm{~m} \mathrm{~s}^{-1}\right)$ behind the cold front extending from the Gulf of Lion to $150 \mathrm{~km}$ north of the Algerian coastline, 2) a region with weak westerly to south-westerly winds $\left(3-7 \mathrm{~m} \mathrm{~s}^{-1}\right)$ ahead of the front along the northern coastlines of Algeria and Tunisia and over the Tyrrhenian Sea, and 3) a region with moderate south-easterly winds (5-10 m $\mathrm{s}^{-1}$ ) over the Strait of Sicily and downstream of the Strait of Messina. Over the southern Tyrrhenian Sea $\left(13^{\circ} \mathrm{E}, 38.5^{\circ} \mathrm{N}\right)$, the weak westerly $\left(\leq 5 \mathrm{~m} \mathrm{~s}^{-1}\right)$ and the moderate south-easterly winds $\left(\sim 10 \mathrm{~m} \mathrm{~s}^{-1}\right)$ converged. Meanwhile, along the western coast of Sicily, the moderate south-easterlies $\left(5-10 \mathrm{~m} \mathrm{~s}^{-1}\right)$ 
over the Sicily Channel abruptly turned to south-westerly around the northern tip of the island (Fig. 4a), converging with the weak westerlies (about $11^{\circ} \mathrm{E}, 38^{\circ} \mathrm{N}$ ), where the MCS A developed.

Over the Tyrrhenian Sea, where the surface south-westerlies $\left(3-7 \mathrm{~m} \mathrm{~s}^{-1}\right)$ were captured by OSCAT (Fig. 4a), the daily composite of the MODIS (Fig. 7a) shows high values of TIWV between $30-35 \mathrm{~kg} \mathrm{~m}^{-2}$ (in agreement with TIWV computed from the radiosonde in Trapani that was $\sim 31 \mathrm{~kg} \mathrm{~m}^{-2}$ at 1200 UTC). About $75 \%$ of the TIWV (about $23-26 \mathrm{~kg} \mathrm{~m}^{-2}$ ) was distributed between surface and 700 $\mathrm{hPa}$ (not shown). Even higher TIWVs $\left(35-40 \mathrm{~kg} \mathrm{~m}^{-2}\right)$ were attained over the Strait of Sicily where south-southwesterly winds $\left(5-10 \mathrm{~m} \mathrm{~s}^{-1}\right.$ ) at the surface (Fig. 4a) were observed by OSCAT. Conversely, the mistral wind region was characterized by low TIWVs $\left(\leq 20 \mathrm{~kg} \mathrm{~m}^{-2}\right)$.

These large TIWV values over the Strait of Sicily were associated with an elevated moist plume coming from tropical Africa as shown by the PIWV composite (Fig. 7b). The south-west to north-east elongated moist filament was characterized by PIWV values between 7 and $15 \mathrm{~kg} \mathrm{~m}^{-2}$. High PIWV values $\left(7-11 \mathrm{~kg} \mathrm{~m}^{-2}\right)$ were observed with MODIS in the vicinity of MCSs A and B. Similar features have been identified by Chazette et al. (2015b) for another HPE over the Cévennes during IOP 15b. As in Chazette et al. (2015b), the elevated moist filament was associated with strong south-westerlies $\left(25-30 \mathrm{~m} \mathrm{~s}^{-1}\right)$ at $700 \mathrm{hPa}$ level (not shown) ahead of a pronounced trough positioned over Eastern France. In our case, elevated moisture may have strengthened the updrafts associated with the V-shaped MCS A once deep convection was initiated.

More details on the vertical structure of the moisture field are provided by LEANDRE 2-derived WVMR observations. Figure 6 shows the ATR flight track (black line) together with the BT observed at $6.2 \mu \mathrm{m}$ with SEVIRI at the time when the ATR was flying closest to MCS A ( 0930 UTC). The vertical structure of the moisture field upstream of the MCS was characterized using LEANDRE 2derived WVMR observations (Fig. 8a) where three distinct layers with different WVMR characteristics can be identified. A moist marine atmospheric boundary layer (MABL) with WVMRs on the order of $10-12 \mathrm{~g} \mathrm{~kg}^{-1}$ was seen to deepen from $\sim 600 \mathrm{~m}$ amsl offshore of Corsica to almost $2000 \mathrm{~m}$ amsl in the vicinity of MCS A (located around $39^{\circ} \mathrm{N}$, see the star in Fig. 8a). Low-level moisture is one of the main ingredients of the mesoscale environment enabling heavy precipitation (Ricard et al. 2012). Moreover, 
the low-level moisture seen in Fig. 8a in the region of MCS A possibly contributed to increase the CAPE in the region of interest over the Tyrrhenian Sea, thereby producing larger storms with stronger peak updrafts and low-level downdrafts and heavier precipitation (Lerach and Cotton, 2012).

Another striking feature observed was the very dry layer (WVMR less than $\sim 2 \mathrm{~g} \mathrm{~kg}^{-1}$ ) north of MCS A, whose base was slopping from $\sim 5 \mathrm{~km}$ amsl at $41.7^{\circ} \mathrm{N}$ to about $2 \mathrm{~km}$ amsl in the vicinity of the MCS. This dry elevated layer was also observed to thin out towards the south. Back-trajectory analyses (not shown) suggest that this dry air was associated with air masses from the Atlantic Ocean, subsiding from the upper troposphere ahead of the upper-level trough. LEANDRE 2 backscatter measurement indicated that this dry layer was also very clean (i.e. aerosol-free, not shown). This dry feature corresponds to the stripe of elevated $6.2 \mu \mathrm{m}$ BTs observed in Fig. 7 extending from southern Sardinia to central Italy. The structure and origin of the dry layer in the vicinity of MCS A suggests that the cold front has the characteristics of a kata-front (Browning, 1986), and possibly contributed to prolong the lifetime of the MCS.

Between the MABL and the dry air aloft, LEANDRE 2 revealed the presence of a layer with intermediate WVMR values $\left(\sim 5 \mathrm{~g} \mathrm{~kg}^{-1}\right)$. It is worth noting that most of the isolated clouds observed by lidar north of MCS A (e.g. around $41.3^{\circ} \mathrm{N}$ or $40.1^{\circ} \mathrm{N}$ ) extended up to the top of the intermediate layer, just below the dry layer. Finally, upstream of MCS A, the lower troposphere above MABL was observed to be moister than immediately north of MCS A by as much as 3-4 $\mathrm{g} \mathrm{kg}^{-1}$ between $2-4 \mathrm{~km}$ amsl.

In addition to the dry feature observed over the Tyrrhenian Sea described above, it is also worth noting the region of high BTs (drier upper-level troposphere) in the western part of the domain in Fig. 7, which was associated with the upper-level trough positioned over eastern France. The largest BTs are observed over the Gulf of Lion where the dry wind is blowing from the continent. A well-defined gradient on $6.2 \mu \mathrm{m} \mathrm{BT}$ is observed over the sea. Those high BT values corresponding to dry, cloud-free upper-level air masses (high BT values at $10.8 \mu \mathrm{m}$ in Fig. 4) were observed to move eastward between 1300-1600 UTC (Fig. 4).

\subsection{AROME-WMED analyses}


Over the southern Tyrrhenian Sea, a region of high TIWV ( $\geq 35 \mathrm{~kg} \mathrm{~m}^{-2}$, Fig. 9a) and high CAPE (larger than $1500 \mathrm{~J} \mathrm{~kg}^{-1}$, red contour line in Fig. 9c) is seen in the AROME-WMED analyses at $1200 \mathrm{UTC}$ around $13^{\circ} \mathrm{E} / 39^{\circ} \mathrm{N}$, i.e. where the V-shaped MCS A described above was observed. The high TIWVs $\left(35-40 \mathrm{~kg} \mathrm{~m}^{-2}\right)$ over the southern Tyrrhenian Sea and the Strait of Sicily were in agreement with the MODIS-derived TIWVs (Fig. 7a). A good agreement between AROME-WMED and LEANDRE 2 observations is found above the MABL, between 2-4 km amsl (see Fig. 8c-d), while some relatively large differences can be seen in the lower troposphere in the area just upstream of the MCS. Here the lowest $1000 \mathrm{~m}$ of the atmosphere appears too moist in the AROME-WMED simulation with respect to the observations, by about $3-4 \mathrm{~g} \mathrm{~kg}^{-1}$ (Fig. 8d). This error can possibly be ascribed to the presence of clouds causing biases in the water vapour measurements in that region.

Consistent with OSCAT observations (Fig. 4), the strong convergence between south-westerlies and southerlies winds $\left(6-8 \times 10^{-4} \mathrm{~s}^{-1}\right)$ is depicted over the southern Tyrrhenian Sea and over the northern Sicily Strait in the AROME-WMED analyses (Fig. 9b). Furthermore, the mistral flow behind the cold front is also reproduced in the AROME-WMED analyses at 1200 UTC and is characterised by dry air masses (TIWV $\leq 20 \mathrm{~kg} \mathrm{~m}^{-2}$, Fig. 9a), strong north-westerly winds at $925 \mathrm{hPa}\left(\sim 20 \mathrm{~m} \mathrm{~s}^{-1}\right.$, Fig. 9b) and low 2-m temperatures (less than $19^{\circ} \mathrm{C}$, Fig. 9c). Over this region, low wet-bulb potential temperatures $\left(\theta_{\mathrm{w}} \leq 280 \mathrm{~K}\right.$, Fig. 9d) were simulated at $850 \mathrm{hPa}$ and intense south-westerlies prevailed at $500 \mathrm{hPa}$ level. The leading edge of the mistral forms an arc spanning from $4^{\circ} \mathrm{E} / 38^{\circ} \mathrm{N}$ to $11^{\circ} \mathrm{E} / 44^{\circ} \mathrm{N}$ with a marked convergence (Fig. 9b) along the between of the geopotential iso-contours of $5480 \mathrm{~m}$ and $5520 \mathrm{~m}$, and higher $\theta_{\mathrm{w}}$ of $285-290 \mathrm{~K}$ (Fig. 9d).

In this favourable environment, MCS A develops ahead of the cold front in correspondence with the high temperature and large moisture contents from the Sicily Channel and low-level convergence caused by the confluence of the weak westerlies in the south Tyrrhenian Sea ahead of the frontal region and the south-westerly flow with the large CAPE. The triggered narrow V-shape MCS A lasted for many hours over the southern Tyrrhenian Sea propagating toward the SI together with the southeastward moving front. 


\section{Environmental characteristic of MCS B}

MCS I, II and B crossed a region of strong SST gradient in the Strait of Sicily, around the buoy location (Fig. 10a). High SSTs on the order of $27^{\circ} \mathrm{C}$ prevailed to the south of the Sicily Channel, while SSTs around $23^{\circ} \mathrm{C}$ where observed in the vicinity of the buoy (around $11.5^{\circ} \mathrm{E}, 37.5^{\circ} \mathrm{N}$, Fig. $10 \mathrm{a}-\mathrm{b}$ ). The storm track of MCSs I, II and B and the BT signature of the three MCSs at the location of the buoy can be seen in Fig. 10b. The SST measured by the buoy was $23.2^{\circ} \mathrm{C}$ during most of 14 October and the morning of 15 October indicating no change caused by the passage of MCS I (Fig. 10b). No precipitation associated with MCS I was recorded by the rain gauge closest to the location of the buoy in the western part of Sicily ( $\sim 95 \mathrm{~km}$ away, circle in Fig. $\left.10 ; 12.5^{\circ} \mathrm{E}, 38^{\circ} \mathrm{N}\right)$. Around $12 \mathrm{UTC}$ on 15 October, SST dropped to $23.1^{\circ} \mathrm{C}$, simultaneously with the passage of MCS II. This was likely due to surface cooling by rain (rainfall was observed over Sicily $\sim 4 \mathrm{~h}$ after the minimum of $10.8 \mu \mathrm{m}$ BT observed at the location of the buoy).

Subsequently, the SST further dropped to $22.9^{\circ} \mathrm{C}$, concomitant to the passage of MCS B around 1600 UTC. Here again the cooling was probably associated with precipitation, since rainfall was observed $\sim 4$ h later over western Sicily. Greater rainfall amounts associated with MCS B (i.e. maximum of $17 \mathrm{~mm} \mathrm{~h}^{-1}$ at $2100 \mathrm{UTC}$ ) may also explain the stronger cooling (i.e. $0.2^{\circ} \mathrm{C}$ ) than that associated with MCS II $\left(0.1^{\circ} \mathrm{C}\right.$ for the maximum rainfall of $\left.6 \mathrm{~mm} \mathrm{~h}^{-1}\right)$. Finally, after the passage of MCS B over the buoy (i.e. after $1800 \mathrm{UTC}$ ), $10.8 \mu \mathrm{m}$ BTs were observed to be on the order of $285 \mathrm{~K}$, revealing the absence of deep convection, as the dry air mass associated with the upper-level trough moved over this area.

At 2100 UTC, MCS B was located just east of the eastward-moving upper-level trough (as revealed from SEVIRI $6.2 \mu \mathrm{m}$ BTs, Fig. 11a) and the associated low-level cold front. The position of the BT arc-shaped feature coincides with the $10 \mathrm{~kg} \mathrm{~m}^{-2}$ iso-contour in the TIWV field displayed by the AROME-WMED analysis (Fig. 12a). MCS B was located in a moist environment east of this isocontour characterized by the TIWV values in excess of $35 \mathrm{~kg} \mathrm{~m}^{-2}$. This elongated feature of the humidity field was associated with the tropical moist plume previously identified (TIWV in Trapani reached 30 $\left.\mathrm{kg} \mathrm{m}^{-2}\right)$. 
During P2, OSCAT (Fig. 5a) showed that the mistral reached northern Africa and penetrated over the Strait of Sicily while being accelerated by channelling between Sicily and Tunisia. Meanwhile, the northerlies converged with the frontal westerlies $\left(5-10 \mathrm{~m} \mathrm{~s}^{-1}\right)$ to the north and south of MCS B ahead of the mistral.

At higher levels $(500 \mathrm{hPa})$, strong south-westerlies $\left(\sim 30 \mathrm{~m} \mathrm{~s}^{-1}\right)$ prevailed ahead of the cold front and upstream of the SI area (Fig. 12d), while the mistral area was topped by strong north-westerlies $\left(\sim 25 \mathrm{~m} \mathrm{~s}^{-1}\right)$. The warm $\theta_{\mathrm{w}}(\geq 290 \mathrm{~K})$ at $850 \mathrm{hPa}$, between geopotential iso-contours of $5560 \mathrm{~m}$ and 5640 $\mathrm{m}$, appeared to be associated with the front. Ahead of the front, a broad region characterized by strong low-level convergence $\left(8.5 \times 10^{-4} \mathrm{~s}^{-1}\right)$ was identified by AROME-WMED (Fig. 12b). Simultaneously, warm air temperatures $\left(\geq 24^{\circ} \mathrm{C}\right)$ as well as a fairly small area of high CAPE $\left(\geq 1000 \mathrm{~J} \mathrm{~kg}^{-1}\right.$, black contour line in Fig. 12c) were displayed upstream of the MCS B. The high CAPE region previously observed over Tunisia at 1200 UTC (Fig. 9c) has moved offshore at 2100 UTC (Fig. 12c), south of Sicily. This was likely related to the progression of the dry low-level mistral flow, which reached the Strait of Sicily at 2100 UTC (Fig. 12b).

These favourable environmental conditions determined by the combination of strong convergence ahead of the cold front in the Strait of Sicily, large low-level moisture contents, warm SST, and high air temperature enabled the maintenance of the huge V-shape MCS B over the Strait of Sicily. Furthermore, we also acknowledge the fact that the cold front and/or the upward forcing associated to the advancing branch of the upper level trough could favour upward vertical motion at synoptic scale, as suggested by Barthlott and Davolio (2015).

After P2, dry air masses (as revealed from SEVIRI $6.2 \mu \mathrm{m}$ BTs, e.g. at $0600 \mathrm{UTC}$, Fig. 11b) associated with the upper-level trough progressing eastward together with the low-level mistral flow reached SI, leading to environmental conditions detrimental to deep convection.

\section{Summary}

During IOP 13 (15-16 October 2012) of the HyMeX SOP 1, SI experienced two periods of intense rainfall. The first between 1300 UTC and 1700 UTC on 15 October (period P1, maximum hourly 
precipitation of $34.8 \mathrm{~mm} \mathrm{~h}^{-1}$; total precipitation of $62.4 \mathrm{~mm}$ ), and the second between 2300 and 0200 UTC on 15-16 October (period P2, maximum hourly precipitation of $33.8 \mathrm{~mm} \mathrm{~h}^{-1}$; total precipitation of $75 \mathrm{~mm}$ ). The HPEs were both associated with multicell V-shaped retrograde regeneration MCSs which formed over the Tyrrhenian Sea (responsible for P1) and over Algeria (responsible for P2). The life cycle of the two MCSs in connection with their dynamic and thermodynamic environments were analysed using a combination of ground-based, airborne and spaceborne observations as well as NWP model analyses. The main findings are summarized in schematic illustrations shown Fig. 13.

MCS A was triggered by low-level convergence (hatched area in Fig. 13a) between the low-level south-westerly flow ahead of the cold front and very-moist low-level south-southwesterly flow from the strait of Sicily. During P1, the convection was favoured by high CAPE values (greater than $1500 \mathrm{~J}$ $\mathrm{kg}^{-1}$ ) over the Tyrrhenian Sea resulting from moist conditions in the low-levels (water vapor mixing ratio of $\sim 12 \mathrm{~g} \mathrm{~kg}^{-1}$ in the lower $1 \mathrm{~km}$ of the MABL). Moreover the presence of an elevated moisture plume from tropical Africa contributed about one quarter of the large observed TIWV $\left(\sim 35 \mathrm{~kg} \mathrm{~m}^{-2}\right)$, favouring the efficiency of the convection to produce more precipitation. After the initiation phase, the V-shaped MCS moved eastward but remained over the southern Tyrrhenian Sea. According to SEVIRI observations, it lasted for more than $14 \mathrm{~h}$.

Heavy precipitation during P2 was caused by a MCS initiated over Algeria around 1300 UTC, which subsequently moved over the Strait of Sicily toward Sicily and SI. Convection was favoured by the combination of the large low-level moisture contents and high SSTs in the Sicily Channel $\left(\sim 23^{\circ} \mathrm{C}\right)$ as well as by a marked wind convergence ahead of the front (Fig. 13b). Unlike other MCSs forming in the same region earlier on that day, the huge V-shape system did affect SI because the strong flow ahead of the upper-level trough progressively veered from southwesterly to south-southwesterly thereby guiding the MCS towards SI. The penetration of the mistral in the Strait of Sicily at the end of 15 October (dashed line Fig. 13b) terminated the convective activity west of Sicily. Ultimately, dry air masses associated with low-level mistral and the upper-level trough overpassed SI, terminating the HPE over SI during IOP 13.

Using as much of the available data as possible in combination with numerical simulations, we show 
the importance of the southerly flow from the warmer Mediterranean south of Sicily in enhancing the convergence ahead of the large-scale cold front and feeding moisture into the developing MCSs upstream of SI. We also detail the initiation and maintenance processes for MCSs occurring along the previously identified autumnal convective arc between Tunisia, Sicily and SI which appears to be a prominent area of initiation of MCSs leading to HPEs over SI as shown by others (e.g. Funatsu et al., 2009). Furthermore, we highlight the role of the upper-level trough over southern France, extending to Algeria over the Western Mediterranean in organizing convection along the autumnal convective arc. These results suggest that in order to improve model forecasts of the MCSs along this autumnal convection arc as well as HPEs over Sicily and SI, the simulation domain needs to include northern Africa and part of the Eastern Mediterranean Basin.

As stated in Barthlott and Davolio (2015), it is very difficult for NWP models to simulate accurately the triggering of isolated convection systems (such as MCS A), which are usually associated with low intrinsic predictability. On the other hand, MCS B, that develops later in the evening and is triggered directly by the frontal passage, is better described in their model simulations. Complementary investigations of the HPEs occurring over SI during IOP 13 will be conducted with a high resolution model to enhance our comprehension of the impact of elevated moisture transport from tropical Africa and of the dry air masses observed north of MCS A on the development of deep convection upstream of SI. In addition, sensitivity experiments will be also used to determine whether the rainfall observed during P2 over southern Italy is of convective or stratiform nature.

\section{Acknowledgements}

This work was supported by the French Agence Nationale de la Recherche (ANR) via the IODA-MED Grant ANR-11-BS56-0005, the MUSIC grant ANR-14-CE01-014 and the MISTRALS/HyMeX programme. Airborne data was obtained using the ATR-42 Environment Research Aircraft operated and managed by Service des Avions Français Instrumentés pour la Recherche en Environnement (SAFIRE), which is a joint entity of CNRS, Météo-France \& CNES (http://www.safire.fr). The SAFIRE staff is thanked for their support during the SOP 1. The authors are grateful to D. Bruneau, P. Genau, 
C. Merlet, R. Meynadier, T. Deleporte, S. Bastin, C. Kocha, C. Lavaysse (LATMOS) as well as F. Blouzon and A. Abchiche (DT/INSU) for operating the LEANDRE 2 system aboard the ATR-42 during the HyMeX-SOP 1. The authors would also like to thank I. Taupier-Letage (MIO) for discussions and O. Bock (IGN) for the GPS data. The authors warmly thank Dr P. Rosenberg (School of Earth and Environment, University of Leeds) for his support in improving the English of the paper. Finally, the authors are grateful to the three anonymous referees whose comments helped improved the paper significantly. LEANDRE 2 data are available from the HyMeX Database: http://dx.doi.org/10.6096/HYMEX.WATER_VAPOUR_DIAL_LEANDRE2.V1.20120911. AROMEWMED analyses are also available from the HyMeX database: http://dx.doi.org/10.6096/HYMEX.AROME_WMED.2012.02.20.

\section{References}

Barthlott C, Davolio S. 2015. Mechanisms initiating heavy precipitation over Italy during the HyMeX Special Observation Period 1: A numerical case study using two mesoscale models. Q. J. R. Meteorol. Soc. DOI: 10.1002/qj.2630.

Barthlott C, Adler B, Kalthoff N, Handwerker J, Johler M, Wieser A. 2014. The role of Corsica in initiating nocturnal offshore convection. Q. J. R. Meteorol. Soc. doi: 10.1002/qj.2415.

Bedka K, Brunner J, Dworak R, Feltz W, Otkin J, Greenwald T. 2009. Objective satellite-based detection of overshooting tops using infrared window channel brightness temperature gradients. J. Appl. Meteorol. Climatol. 49: 181-202.

Bedka K. 2011. Overshooting cloud top detections using MSG SEVIRI Infrared brightness temperatures and their relationship to severe weather over Europe. Atmos. Res. 99: 175-189. doi: 10.1016/j. atmosres.2010.10.001.

Bock O, Bosser P, Pacione R, Nuret M, Fourrié N, Parracho A. 2015. A high quality reprocessed groundbased GPS dataset for atmospheric process studies, radiosonde and model evaluation, and reanalysis of HyMeX special observing period. Q. J. R. Meteorol. Soc. doi :10.1001/qj.2701.

Brousseau P, Bouttier F, Hello G, Seity Y, Fischer C, Berre L, Montmerle T, Auger L, Malardel S. 2008. 
A prototype convective-scale data assimilation system for operation: The AROME-RUC. HIRLAM Tech. Rep. 68: 23-30.

Browning KA. 1986. Conceptual models of precipitation systems. Wea. Forecasting, 1: 23-41.

Bruneau D, Quaglia P, Flamant C, Meissonnier M, Pelon J. 2001a. Airborne Lidar LEANDRE 2 for water vapour profiling in the Troposphere. System description. Appl. Opt. 40: 3450-3461.

Bruneau D, Quaglia P, Flamant C, Pelon J. 2001b. Airborne Lidar LEANDRE 2 for water vapour profiling in the Troposphere. First results. Appl. Opt. 40: 3462-3475.

Campins J, Genovés A, Jansa A, Guijarro JA, Ramis C. 2000. A catalogue and a classification of surface cyclones for the western Mediterranean. Int. J. Climatol. 20: 969-984.

Cailleau S, Chanut J, Lellouche JM, Levier B, Maraldi C, Reffray G, Sotillo MG. 2012. Towards a regional ocean forecasting system for the IBI (Iberia-Biscay-Ireland area): developments and improvements withing the ECOOP project framework. Ocean Sci. 8: 143-159, doi:10.5194/os8-143-2012.

Chazette P, Flamant C, Shang X, Totems J, Raut JC, Doerenbecher A, Ducrocq V, Fourrié N, Bock O, Cloché S. 2015a. A multi-instrument and multi-model assessment of atmospheric moisture variability over the western Mediterranean during HyMeX. Q. J. R. Meteorol. Soc. doi:10.1002/qj.2671.

Chazette P, Flamant C, Raut JC, Totems J, Shang X. 2015b. Tropical moisture enriched storm tracks over the Mediterranean and their link with intense rainfall in the Cevennes-Vivarais area during HyMeX. Q. J. R. Meteorol. Soc. doi:10.1002/qj.2674.

Cohuet JB, Romero R, Homar V, Ducrocq V, Ramis C. 2011. Initiation of a severe thunderstorm over the Mediterranean Sea. Atmos. Res. 100: 603-620.

Courtier P, Freydier C, Geleyn JF, Rabier F, Rochas M. 1991. The ARPEGE project at Meteo-France, ECMWF workshop on numerical methods in atmospheric modelling, 2: 193-231.

Di Girolamo P, Flamant C, Cacciani M, Richard E, Ducrocq V, Summa D, Stelitano D, Fourrié N, Said F. 2016. Observation of low-level wind reversals in the Gulf of Lion area and their impact on the water vapour variability, Q. J. R. Meteorol. Soc. doi:10.1002/qj.2767. 
Drobinski P, Ducrocq V, Alpert P, Anagnostou E, Béranger K, Borga M, Braud I, Chanzy A, Davolio S, Delrieu G, Estournel C, Boubrahmi NF, Font J, Grubisic V, Gauldi S, Homar V, Ivancan-Picek B, Kottmeier C, Kotroni V, Lagouvardos K, Lionello P, Llasat M, Ludwig W, Lutoff C, Mariotti A, Richard E, Romero R, Rotunno R, Roussot O, Ruin I, Somot S, Taupier-Letage I, Tintore J, Uijlen-hoet R, Wernli H. 2014. HyMeX, a 10 year multidisciplinary program on the Mediterranean water cycle, BAMS, 95: 1063-1082.

Drobinski P, Bastin S, Guénard V, Caccia JL, Dabas AM, Delville P, Protat A, Reitebuch O, Werner C. 2005. Summer Mistral at the exit of the Rhône Valley. Q. J. R. Meteorol. Soc. 131: 353-375.

Ducrocq V, Braud I, Davolio S, Ferretti R, Flamant C, Jansa A, Kalthoff N, Richard E, Taupier-Letage I, Ayral PA, Belamari S, Berne A, Borga M, Boudevillain B, Bock O, Boichard JL, Bouin MN, Bousquet O, Bouvier C, Chiggiato J, Ciimini D, Corsmeier U, Coppola L, Cocquerez P, Defer E, Delanoë J, Di Girolamo P, Doerenbecher A, Drobinski P, Dufournet Y, Fourrié N, Gourley JJ, Labatut L, Lambert D, Le Coz J, Marzano FS, Molinié G, Montani A, Nord G, Nuret M, Ramage K, Rison W, Roussot O, Said F, Schwarzenboeck A, Testor P, Van Baelen J, Vincendon B, Aran M, Tamayo J. 2014. HyMeX-SOP1: The Field Campaign Dedicated to Heavy Precipitation and Flash Flooding in the Northwestern Mediterranean. Bull. Am. Meteorol. Soc. 95: 1083-1100. doi:10.1175/BAMS-D-12-00244.1.

Duffourg F, Nuissier O, Ducrocq V, Flamant C, Chazette P, Delanoë J, Doerenbecher A, Fourrié N, Girolamo Di P, Lac C, Legain D, Martinet M, Saïd F, Bock O. 2016. Offshore deep convection initiation and maintenance during HyMeX IOP 16a heavy precipitation event. Q. J. R. Meteorol. Soc. doi:10.1002/qj.2725.

Duffourg F, Ducrocq V. 2013. Assessment of the water supply to Mediterranean heavy precipitation: A method based on finely designed water budgets. Atmos. Sci. Lett. 14: 133-138.

Flamant C, Chaboureau JP, Chazette P, Di Girolamo P, Bourianne T, Totems J, Cacciani M. 2015. The radiative impact of desert dust on orographic rain in the Cevennes-Vivarais area: a case study from HyMeX, Atmos.Chem Phys. 15: 12231-12249.

Flaounas E, Kotroni V, Lagouvardos K, Claud C, Delanoë J, Flamant C, Madonna E, Wernli H. 2015. 
Processes leading to heavy precipitation associated with two Mediterranean cyclones observed during the HyMeX SOP1. Q. J. R. Meteorol. Soc. doi:10.1002/qj.2618.

Fourrié N, Bresson E, Nuret M, Jany C, Brousseau P, Doerenbecher A, Kreitz M, Nuissier O, Sevault E, Bénichou H, Amodei M, Pouponneau F. 2015. Arome-wmed, a real-time mesoscale model designed for the HyMeX special observation periods. Geosci. Model Dev. 8 (2): 1801-1856. doi:10.5194:/gmdd-8-1801-2015.

Funatsu B, Claud MC, Chaboureau JP. 2009. Comparison between the Large-Scale Environments of Moderate and Intense Precipitating Systems in the Mediterranean Region, Mon. Wea. Rev., 137: $3933-3959$.

Jansa A, 1987. Distribution of the Mistral: A satellite observation. Meteor. Atmos. Phys. 36: 201-214. doi: 10.1007/BF01045149.

Jansa A, Genoves A, Picornell MA, Campins J, Riosalido R, Carretero O. 2001. Western Mediterranean cyclones and heavy rain. Part 2: Statistical approach. Meteorol. Appl. 8: 43-56. doi:10.1017/ S1350482701001049.

Kato T. 2006. Structure of the band-shaped precipitation system inducing the heavy rainfall observed over northern Kyushu, Japan on 29 June 1999. J. Meteor. Soc. Japan. 84(1): 129-153.

Kotroni V, Lagouvardos K. 2008. Lightning occurrence in relation with elevation, terrain slope and vegetation cover over the Mediterranean. J. Geophys. Res. doi:10.1029/2008JD010605.

Lerach DG, Cotton WR. 2012. Comparing aerosol and low-level moisture influences on supercell tornadogenesis: three-dimensional idealized simulations. J. Atmos. Sci. 69: 969-987.

Lin YL, Chiao S, Wang TA, Kaplan ML, Weglarz RP. 2001. Some common ingredients for heavy orographic rainfall. Wea. Forecasting, 16: 633-660.

Llasat MC, Llasat-Botija M, Petrucci O, Pasqua AA, Rosselló J, Vinet F, Boissier L. 2013. Towards a database on societal impact of mediterranean floods within the framwork of the HyMeX project. Nat. Hazard Earth Sys. 13(5): 1337-1350, doi:10.5194/nhess-13-1337-2013.

Masson V, Seity Y. 2009. Including Atmospheric Layers in Vegetation and Urban Offline Surface Schemes, J. Appl. Meteorol. Clim. 48: 1377-1397. 
Masson V, Le Moigne P, Martin E, Faroux S, Alias A, Alkama R, Belamari S, Bardu A, Boone A, Bouyssel F, Brousseau P, Brun E, Calvet JC, Carrer D, Decharme B, Delire C, Donier S, Essaouini K, Gibelin AL, Giordani H, Habets F, Jidane M, Kerdraon G, Kourzeneva E, Lafaysse M, Lafont S, Lebeaupin BC, Lemonsu A, Mahfouf JF, Marguinaud P, Mokhtari M, Morin S, Pigeon G, Salgado R, Seity Y, Taillefer F, Tanguy G, Tulet P, Vincendon B, Vionnet V, Voldoire A. 2013. The surfex v7.2 land and ocean surface platform for coupled or offline simulation of earth surface variables and fluxes. Geosci. Model Dev. 6(4): 929-960, doi:10.5194/gmd-6-9292013.

Mc Cann DW. 1983. The enhanced-V: a satellite observable severe storm signature. Mon. Wea. Rev., 111: $887-894$.

Melani S, Pasi F, Gozzini B, Ortolani A. 2013. A four year (2007-2010) analysis of long-lasting deep convective systems in the Mediterranean basin. Atmos. Res., 123: 151-166.

Nuissier O, Ducrocq V, Ricard D, Lebeaupin C, Anquetin S. 2008. A numerical study of three catastrophic precipitating events over southern France. I: Numerical framework and synoptic ingredients. Q. J. R. Meteorol. Soc. 134: 111-130.

Nuissier P, Joly B, Joly A, Ducrocq V, Arbogast P. 2011. A statistical downscaling to identify the largescale circulation patterns associated with heavy precipitation events over southern France. $Q$. $J$. R. Meteorol. Soc. 137: 1812-1827. doi:10.1002/qj.866.

Ricard D, Ducrocq V, Auger L. 2012. A climatology of the mesoscale environment associated with heavily precipitating events over a northwestern mediterranean area. J. Appl. Meteorol. Climatol. 51: 468-488. doi:10.1175/JAMC-D-11-017.1.

Rivrain JC. 1997. Les épisodes orageux à précipitations extrêmes sur les régions méditerranéennes de la France. Phénomènes remarquables n 4, Météo-France, Toulouse, 93 p.

Romero R, Sumner G, Ramis C, Genoves A. 1999. A classification of the atmospheric circulation patterns producing significant daily rainfall in the Spanish Mediterranean area. Int. J. Climatol. 19: $765-785$.

Romero R, Ramis C, Homar V. 2015. On the severe convective storm of 29th October 2013 in the 
Balearic Islands: Observational and numerical study. Q. J. R. Meteorol. Soc. doi:10.1002/qj.2429. Rotunno R, Ferretti R. 2001. Mechanisms of intense Alpine rainfall. J. Atmos. Sci. 58: 1732-1749.

Rotunno R, Houze RA. 2007. Lessons on orographic precipitation from the Mesoscale Alpine Programme. Q. J. R. Meteor. Soc. 133: 811-830.

Rysman JF, Claud C, Chaboureau JP, Delanoë J, Funatsu BM. 2015. Severe convection in the Mediterranean from microwave observations and a convection-permitting model. $Q . J . R$. Meteorol. Soc. doi:10.1002/qj.2611.

Scofield RA. 1985. Satellite convective categories associated with heavy precipitation. Preprints, Sixth Conference on hydrometeorology, October 29, 1985, Indianapolis, Amer. Meteor. Soc., 42-51. Seity Y, Brousseau P, Malardel S, Hello G, Bernard P, Bouttier F, Lac C, Masson V. 2011. The AROMEFrance convective-scale operational model. Mon. Weather. Rev. 139: 976-991, doi:10.1175.2011MWR3425.1.

Setvák M, Rabin RM, Wang PK. 2007. Contribution of the MODIS instrument to observations of deep convective storms and stratospheric moisture detection in GOES and MSG imagery. Atmos. Res. 83: $505-518$.

Trapero L, Bech J, Lorente J. 2013a. Numerical modelling of heavy precipitation events over Eastern Pyrenees: Analysis of orographic effects. Atmos. Res. 123: 368-383.

Trapero L, Bech J, Duffourg F, Esteban P, Lorente J. 2013b. Mesoscale numerical analysis of the historical November 1982 heavy precipitation event over Andorra (Eastern Pyrenees). Nat. Hazards Earth Syst. Sci. 13: 2969-2990.

Trigo IF, Davies TD, Bigg GR. 1999. Objective climatology of cyclones in the Mediterranean region. J. Climate, 12: 1685-1696.

Turato B, Reale O, Siccardi F. 2004. Water vapour sources of the October 2000 Piedmont flood. $J$. Hydrometeorol. 5: 693-712. doi:10.1175/1525-7541(2004)005<0693:WVSOTO>2.0CO;2.

Winschall A, Pfahl S, Sodemann H, Wernli H. 2012. Impact of north Atlantic evaporation hot spots on southern Alpine heavy precipitation events. Q. J. R. Meteorol. Soc. 138: 1245-1258. doi:10.1002/qj.987. 

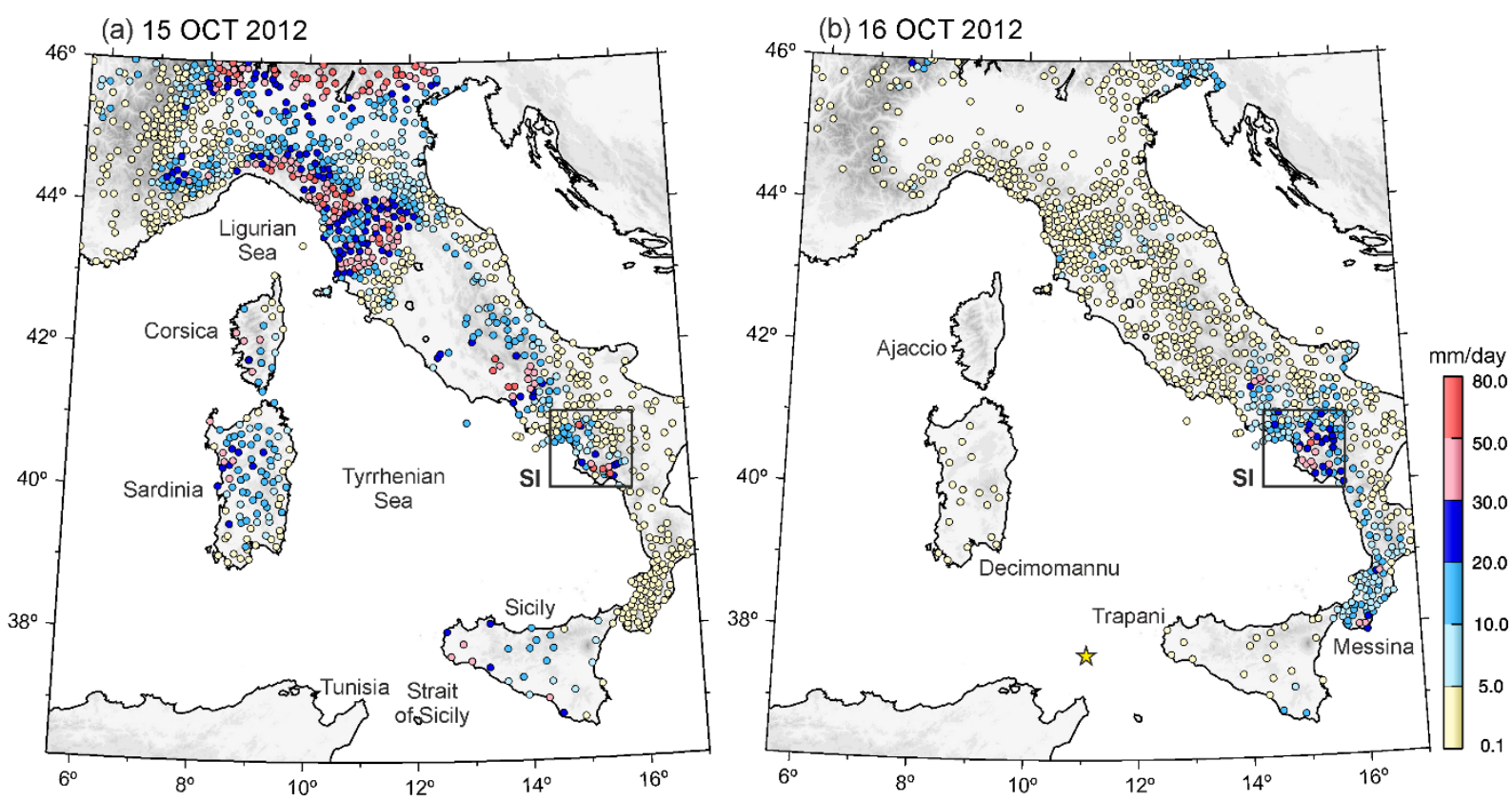

Figure 1. 24-h accumulated rainfall on (a) 15 October and (b) 16 October 2012. The Southern Italy (SI) domain is shown as a black rectangle (from 14.6 to $16.0^{\circ} \mathrm{E}$ and from 40.0 to $41.0^{\circ} \mathrm{N}$ ). A yellow star in (b) indicates the location (around $11.5^{\circ} \mathrm{E}$, $37.5^{\circ} \mathrm{N}$ ) of the buoy measurements acquired during IOP 13 (see text for details). 
(a) $500 \mathrm{hPa}$ ANALYSES

1200 UTC 15 OCT 2012

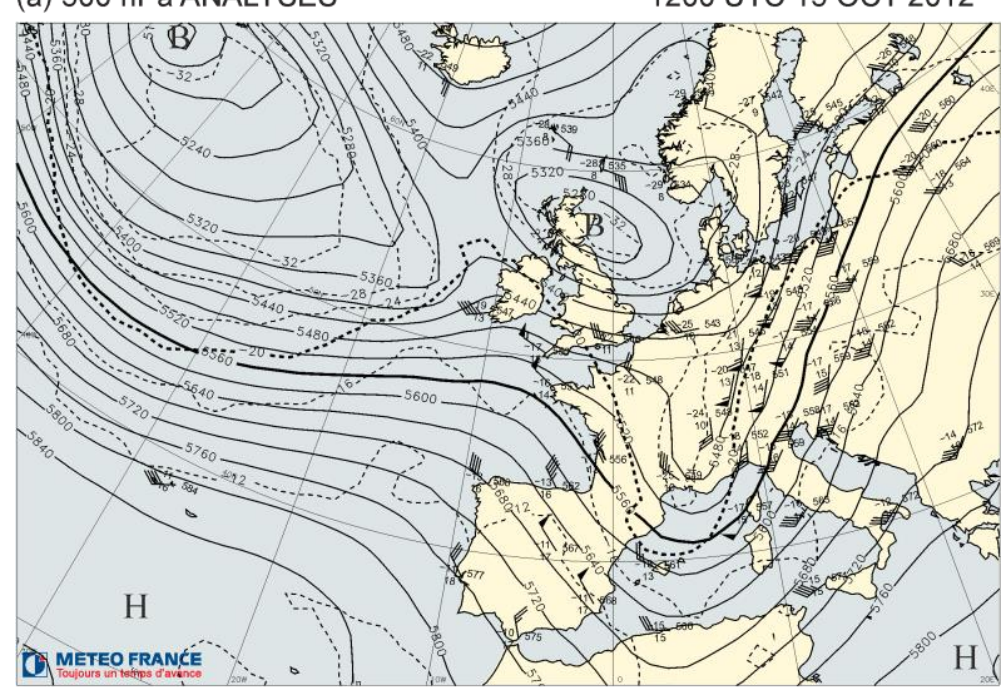

(b) SURFACE ANALYSES

1200 UTC 15 OCT 2012

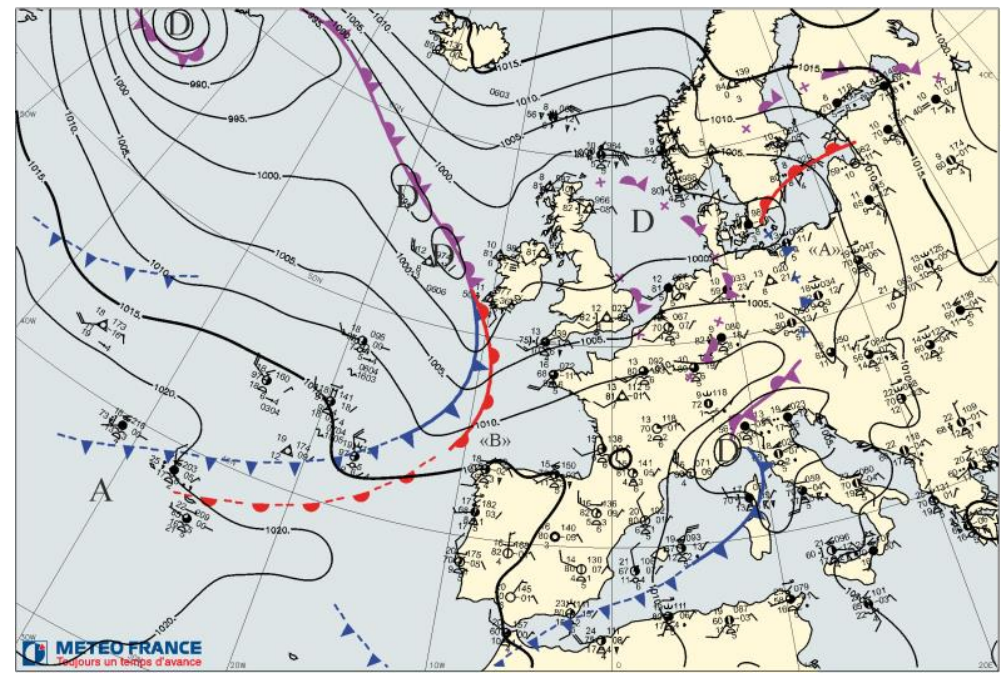

Figure 2. Weather charts at $1200 \mathrm{UTC}, 15$ Oct. 2012. (a) $500 \mathrm{hPa}$ analyses: geopotential height (solid line, $40 \mathrm{~m}$ interval) and temperature (dashed line, $4^{\circ} \mathrm{C}$ interval), and (b) surface analyses: mean sea level pressure (solid line, $5 \mathrm{hPa}$ interval) and fronts (warm fronts in red and cold fronts in blue). 


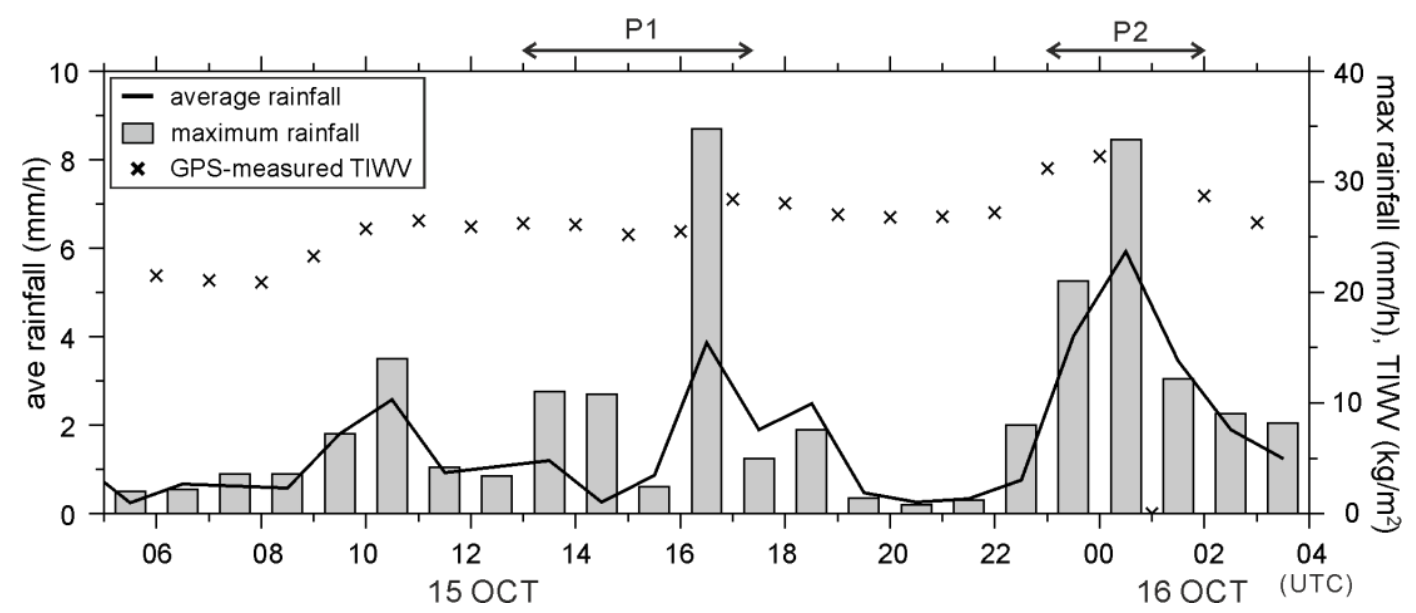

Figure 3. Temporal evolution of observed average hourly rainfall over the SI domain (solid line) and maximum hourly rainfall (bar) within SI domain. The temporal evolution of GPS-derived hourly TIWV from a station located at $15.8^{\circ} \mathrm{E}, 39.9^{\circ} \mathrm{N}$ is also shown (crosses). 
(a) 1300 UTC 15 OCT 2012

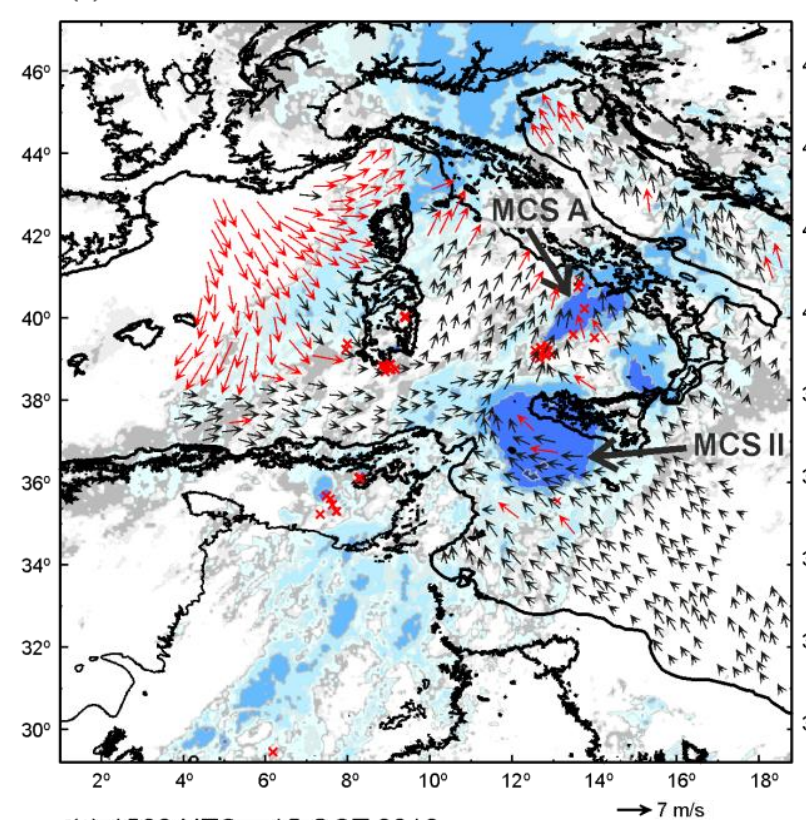

(c) 1500 UTC 15 OCT 2012

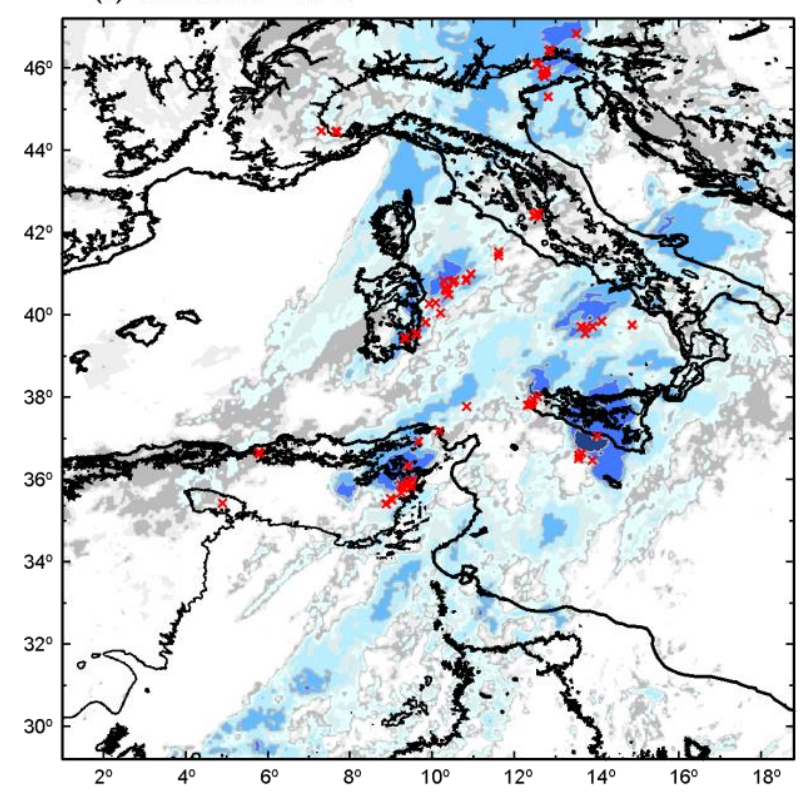

(b) 1400 UTC 15 OCT 2012

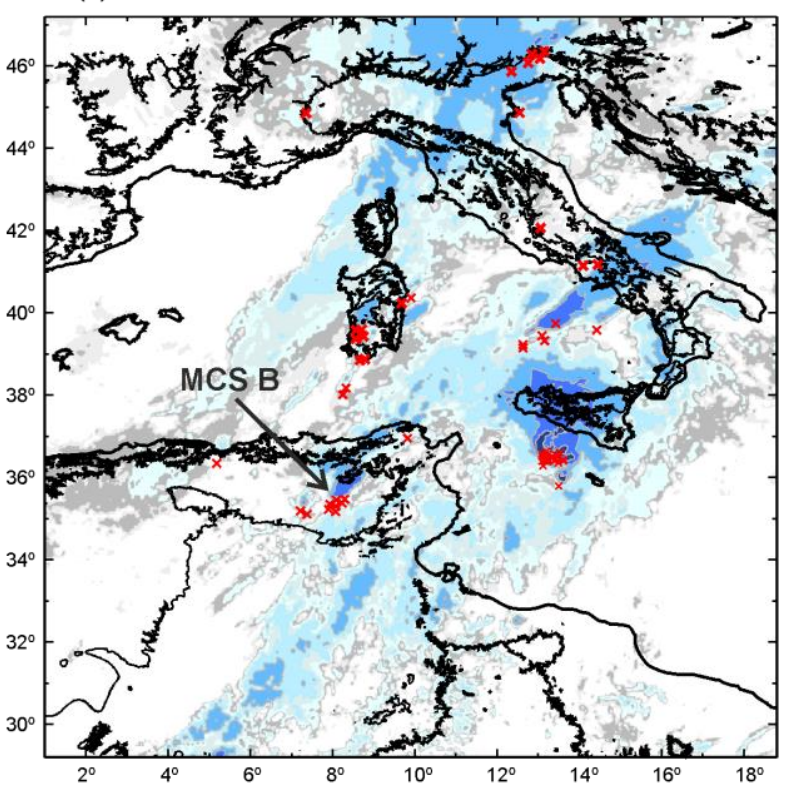

(d) 1600 UTC 15 OCT 2012

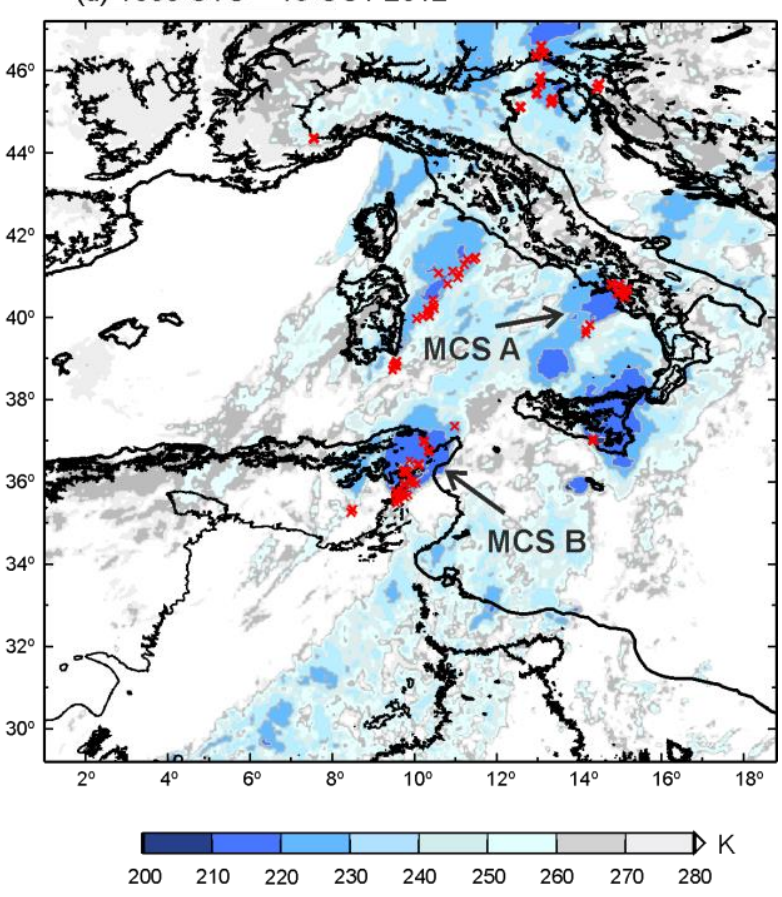

Figure 4. Distribution of brightness temperature at $10.8 \mu \mathrm{m}$ (K) observed with SEVIRI MSG at (a) 1300 UTC, (b) 1400 UTC, (c) 1500 UTC, and (d) 1600 UTC on 15 Oct. 2012. In (a) NOAA OSCAT-retrieved surface winds observed around 1130 UTC are overlaid: red vectors for winds stronger than $10 \mathrm{~m} \mathrm{~s}^{-1}$ and black vectors for winds in between 3-10 $\mathrm{m} \mathrm{s}^{-1}$. Red crosses in (a)-(d) indicate the location of lightning during the 5 minutes preceding the time of SEVIRI imagery. MCS A, MCS B and MCS II are meteorological features of interest (see text for details). 
(a) 2200 UTC 15 OCT 2012

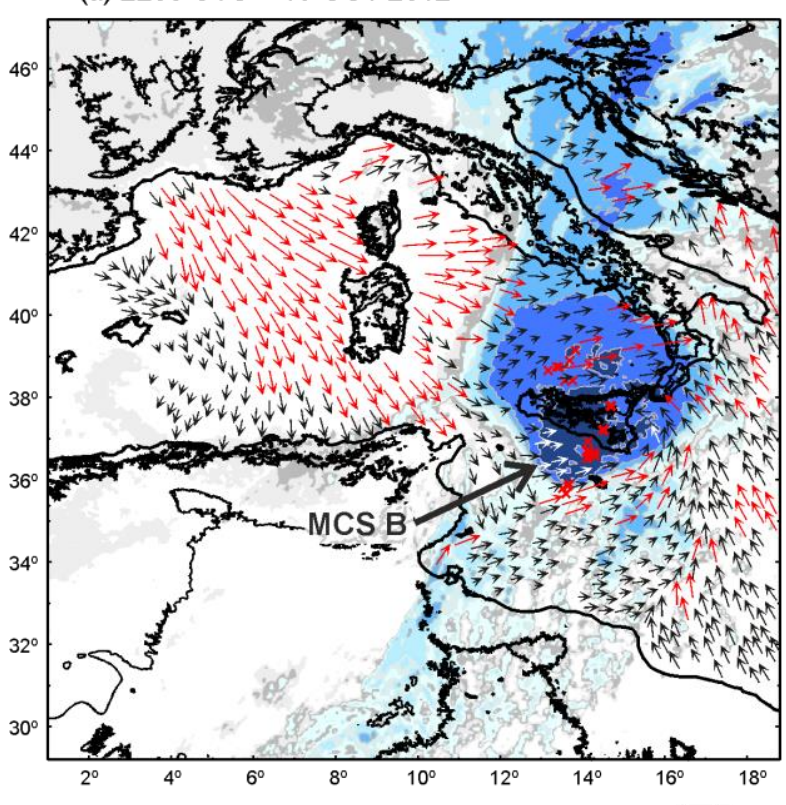

(c) 0000 UTC 16 OCT 2012

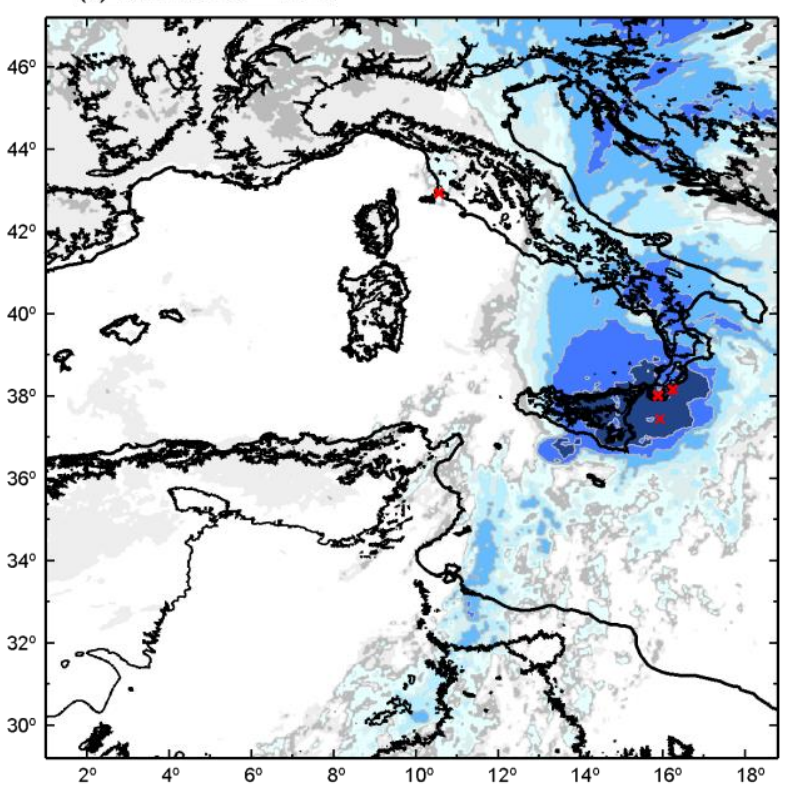

(b) 2300 UTC 15 OCT 2012

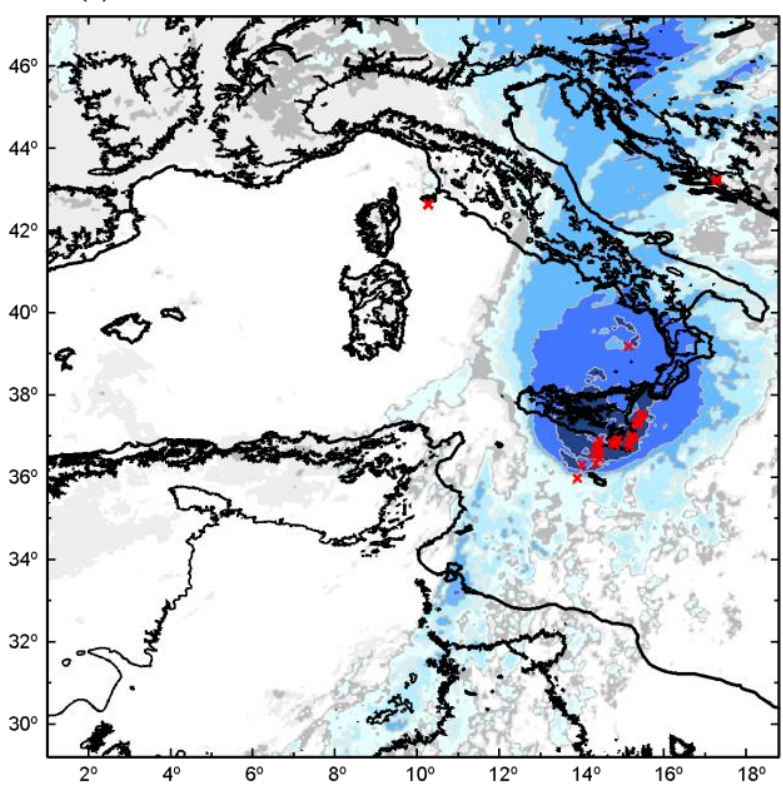

(d) 0100 UTC 16 OCT 2012

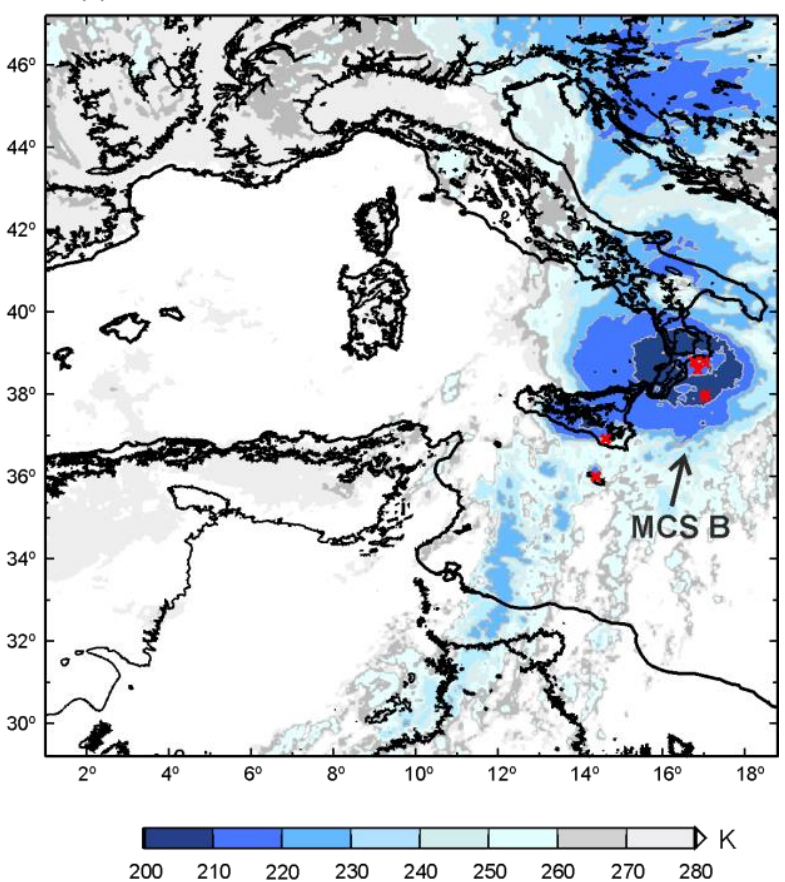

Figure 5. Same as Fig. 4 but at (a) 2200 UTC, (b) 2300 UTC on 15 Oct. 2012, (c) 0000 UTC and (d) 0100 UTC 16 Oct. 2012. In (a) NOAA OSCAT-retrieved surface winds observed around 2235 UTC are overlaid: red vectors for winds stronger than 10 $\mathrm{m} \mathrm{s}^{-1}$ and black vectors (white around the region of low BT with the value $<210 \mathrm{~K}$ ) for winds between $3-10 \mathrm{~m} \mathrm{~s}^{-1}$. MCS B is a meteorological feature of interest (see text for details). 


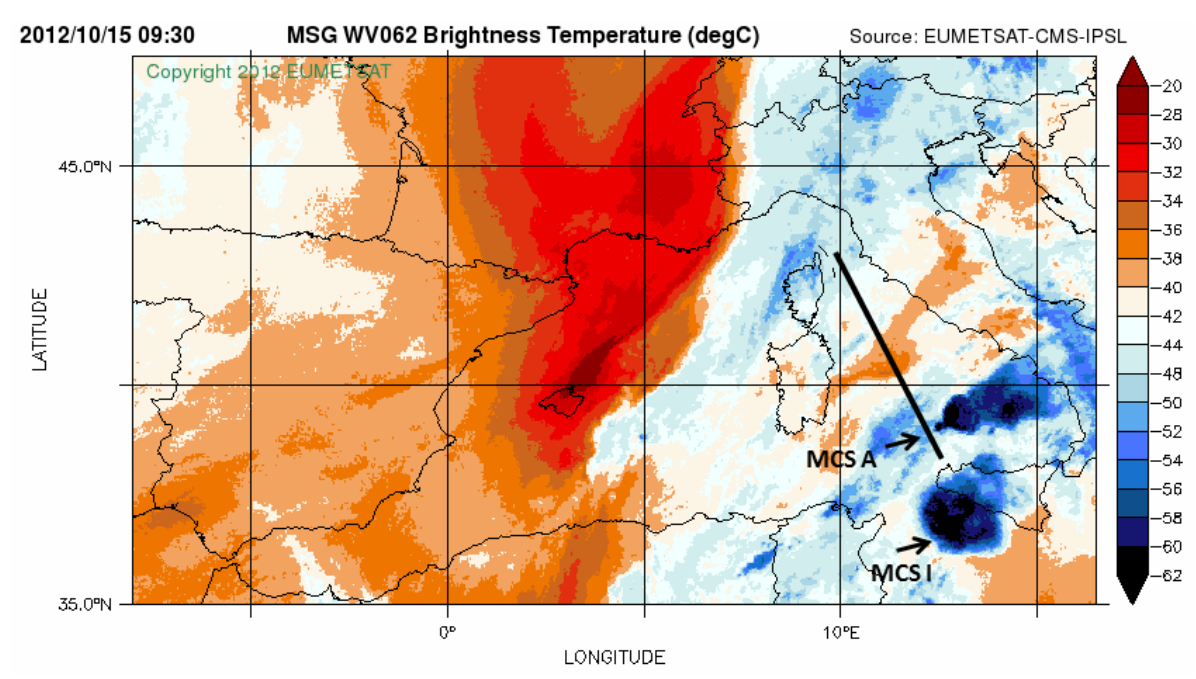

Figure 6. Distribution of brightness temperature at $6.2 \mu \mathrm{m}\left({ }^{\circ} \mathrm{C}\right)$ observed by SEVIRI MSG at 0930 UTC, 15 Oct. 2012. The black line indicates the ATR 42 flight track. MCS A and MCS I are meteorological features of interest (see text for details). 
(a) TIWV (total columns) 15 OCT 2012

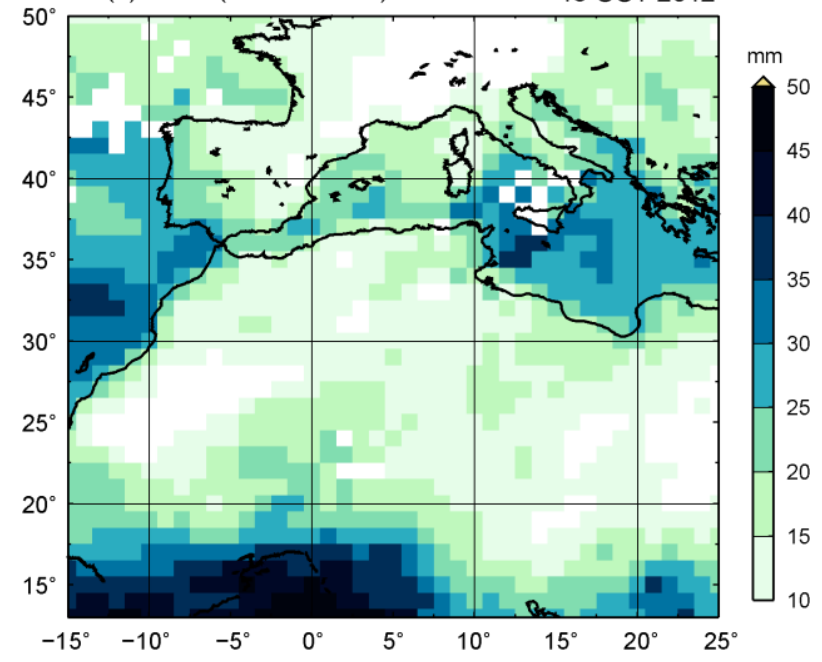

(b) PIWW (700-300 hPa)

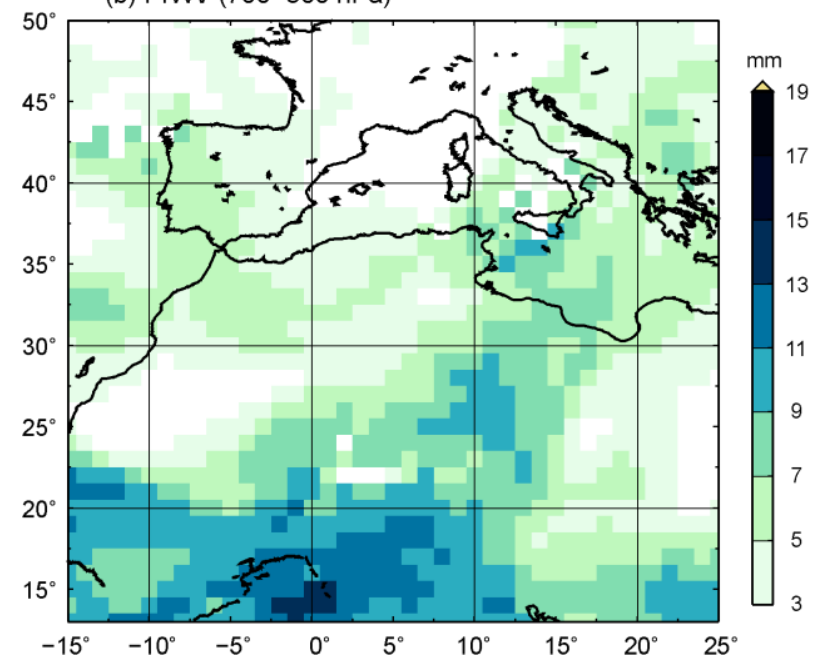

Figure 7. Horizontal distribution of (a) total integrated water vapour content and (b) partial integrated water vapour content between 700 and $300 \mathrm{hPa}$ derived from MODIS/Terra on 15 Oct. 2012. 

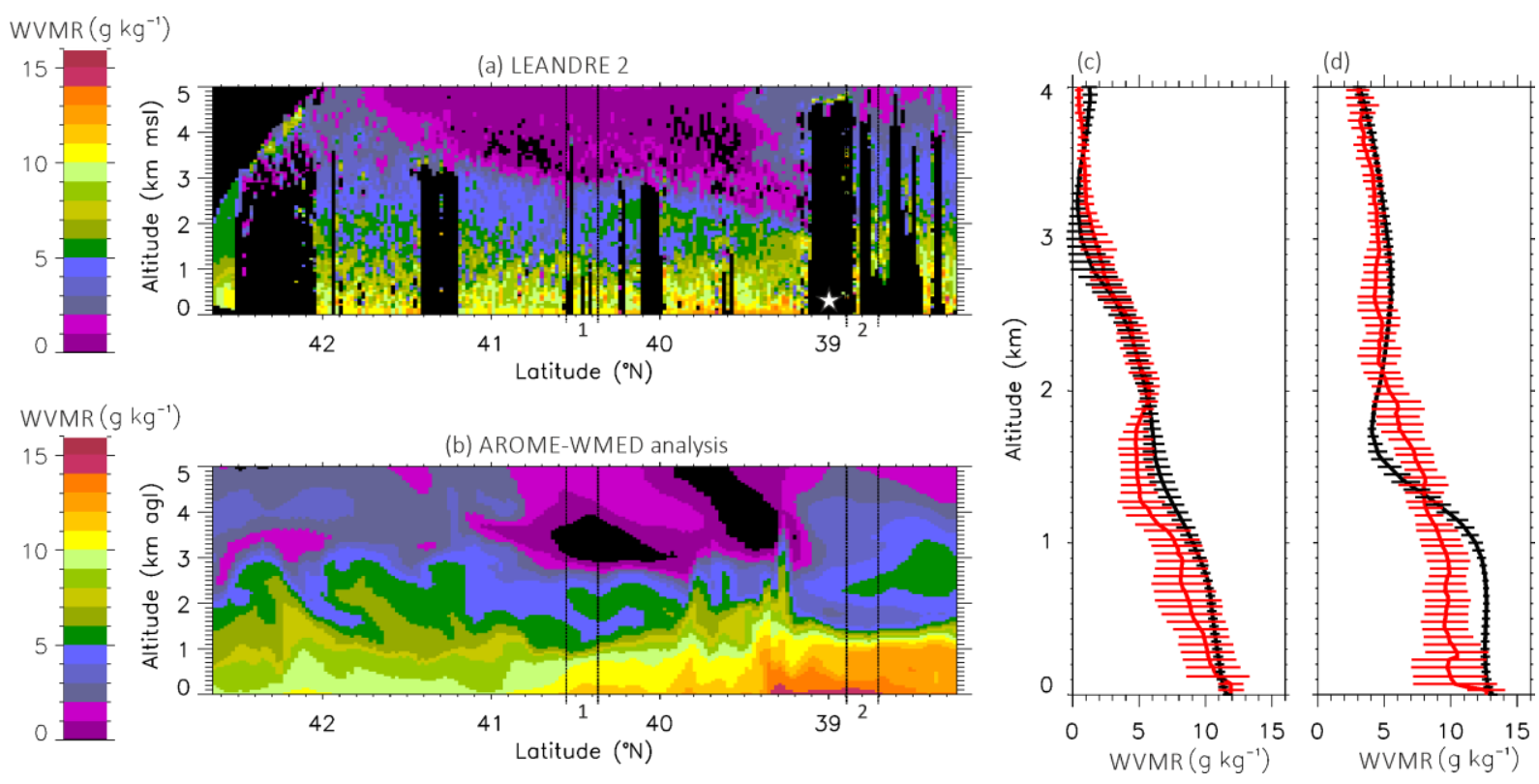

Figure 8. (a) Vertical cross-section of water vapour mixing ratio (WVMR) acquired from LEANDRE 2 along the ATR 42 flight track shown in Fig. 6. (b) Same as (a) but for AROME-WMED. WVMR profiles are extracted along the ATR 42 flight track at the closest time and location of the LEANDRE 2 WVMR profiles. (c) Vertical WVMR profiles obtained from LEANDRE 2 (red solid line) and AROME (black solid line) averaged over $60 \mathrm{~km}$ (area bracketed by 2 vertical solid lines and marked "1" in (a) and (b)). (d) Same as (c), but for the area in (a) and (b) marked "2". Horizontal bars in (c) and (d) are an indication of the natural variability of WVMR around the mean profiles. The length of horizontal bars is equal to 2 times the WVMR standard deviation centred on the profiles. The star in (a) marks the latitude (around $39^{\circ} \mathrm{N}$ ) of MCS A at 0910 UTC. 
1200 UTC 15 OCT 2012

(a) TIWV (AROME, shade), TIWW (GPS, symbol)

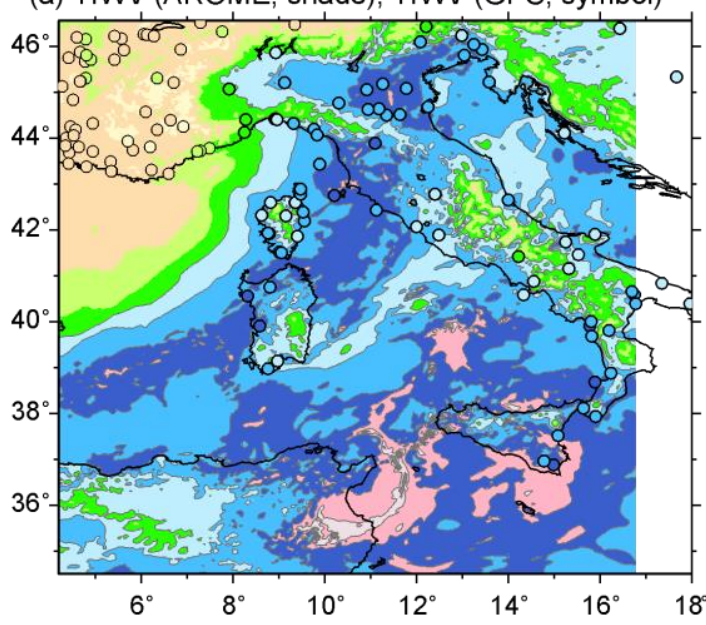

1200 UTC 15 OCT 2012

$\mathrm{Kg} / \mathrm{m}^{2} \quad$ (b) divergence $950 \mathrm{hPa}$ (shade), wind $10 \mathrm{~m}$

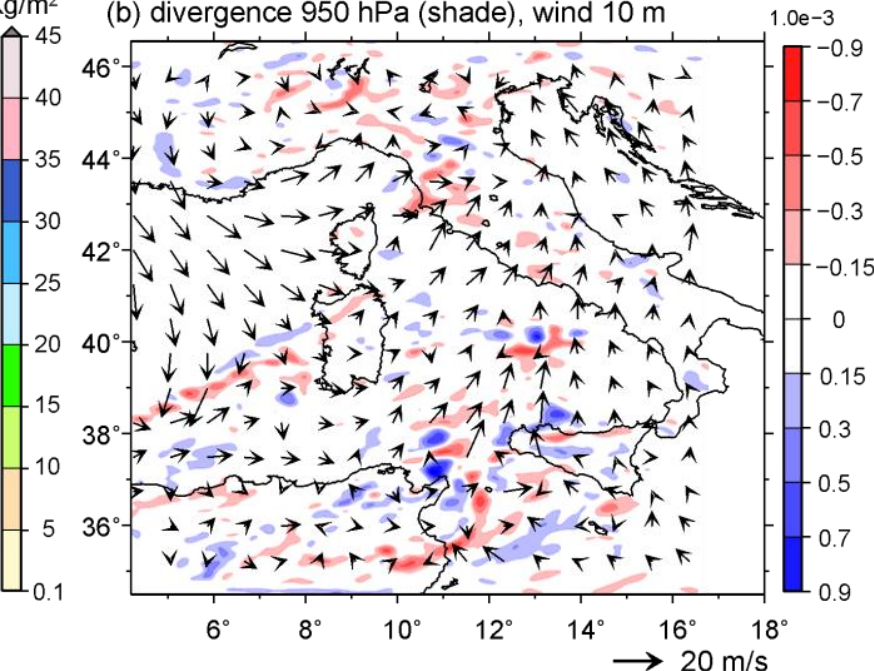

${ }^{\circ} \mathrm{C}$

(c) Temp (shade); Obs (symbol), CAPE (contour) ${ }^{\circ} \mathrm{C}$

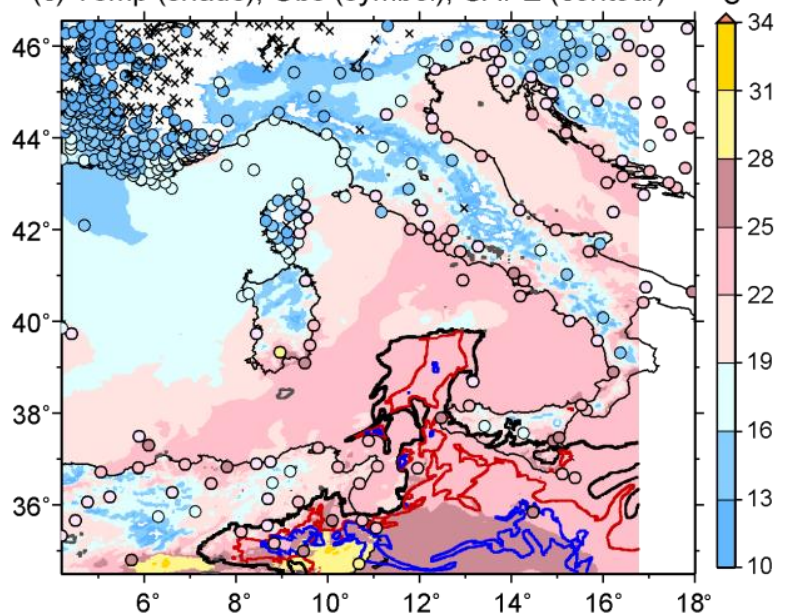

(d) $\theta \mathrm{w} 850 \mathrm{hPa}$ (shade), gepotential, wind $500 \mathrm{hPa}$

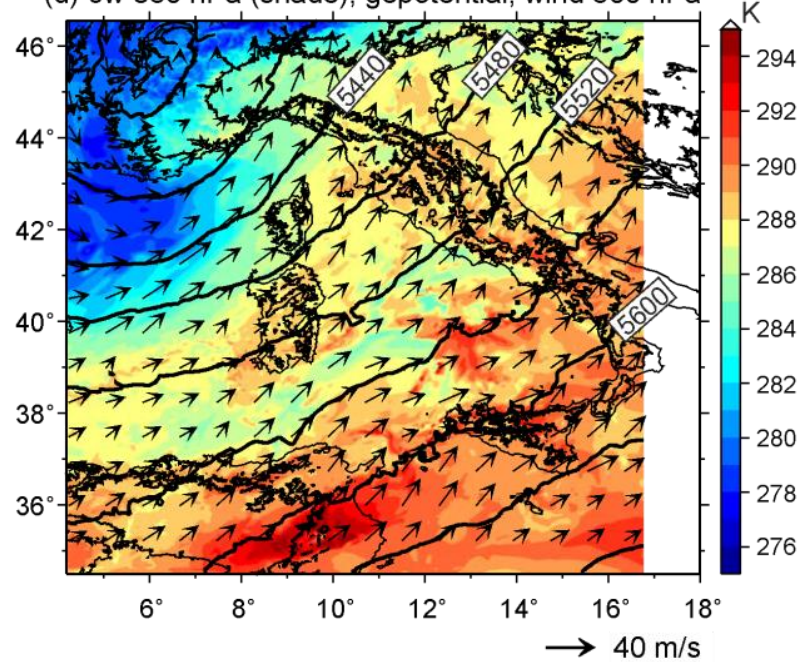

Figure 9. Horizontal distribution of (a) TIWV, (b) $950 \mathrm{hPa}$ divergence (shading) and $10 \mathrm{~m}$ winds (vectors), (c) 2-m temperature (shading) and CAPE (black contour $\left(1000 \mathrm{~J} \mathrm{~kg}^{-1}\right.$ ), red contour $\left(1500 \mathrm{~J} \mathrm{~kg}^{-1}\right)$, and blue contour $\left(2000 \mathrm{~J} \mathrm{~kg}^{-1}\right)$ ) and (d) $850 \mathrm{hPa}$ wet-bulb potential temperature $(\theta \mathrm{w}$, shading) and $500 \mathrm{hPa}$ geopotential (contour, interval of $40 \mathrm{~m}$ ) and wind (vectors) from the AROME-WMED analysis at 1200 UTC, 15 Oct. 2012. Open coloured circles in (a) represent GPS-derived TIWV observations at 1200 UTC. Open coloured circles in (c) represent 2-m temperature observations from SYNOP stations at 1200 UTC. Crosses in (c) represent SYNOP 2-m temperatures less than $10^{\circ} \mathrm{C}$. 

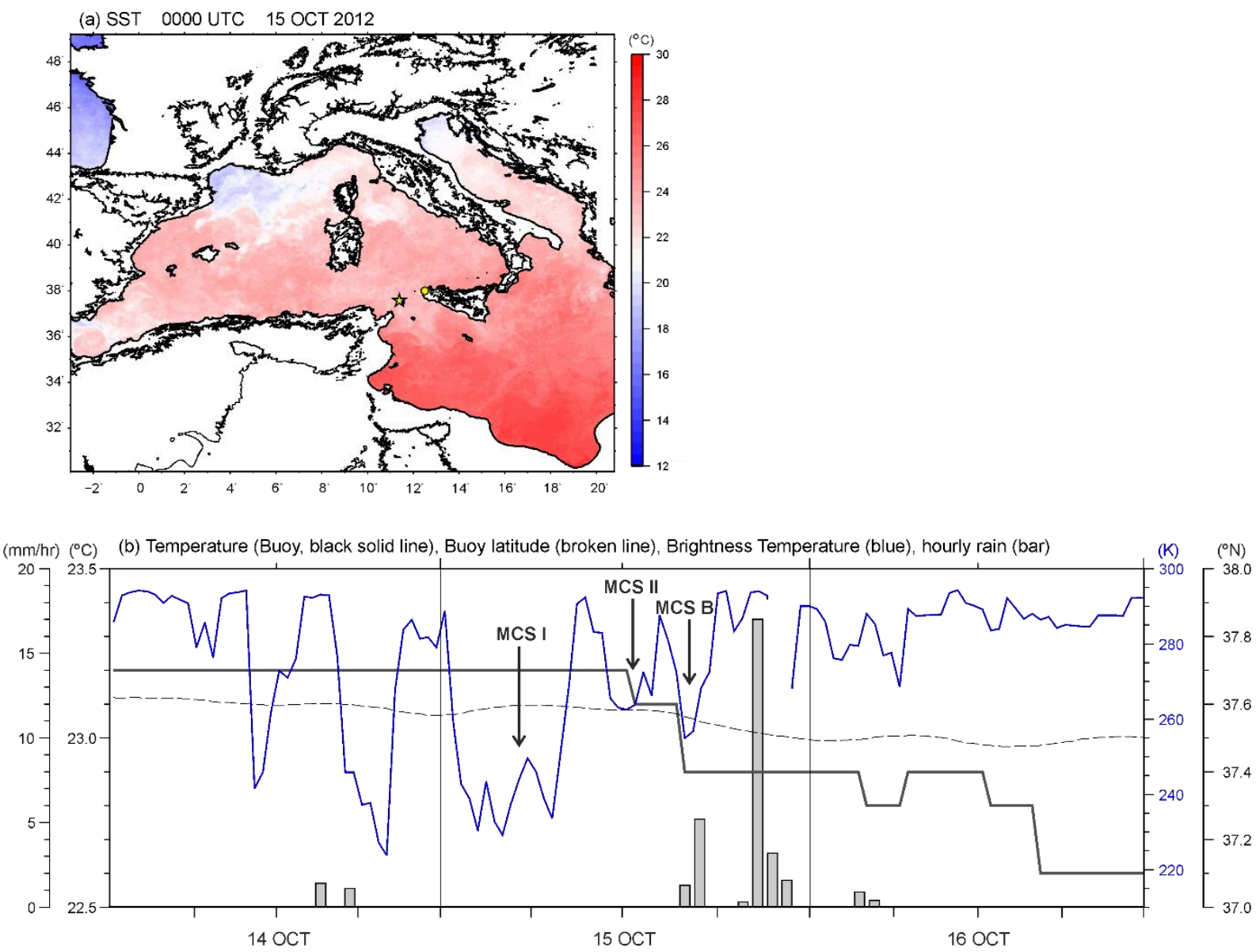

Figure 10. (a) SST distribution obtained from CMS multi-sensor (level 3) product at 0000 UTC, 15 Oct. 2012. The yellow star (circle) indicates the location of the buoy (rain gauge) for which data are shown in (b). (b) Time evolution of the buoy location (latitude ${ }^{\circ} \mathrm{N}$, dashed line) and SST $\left({ }^{\circ} \mathrm{C}\right.$, black solid line) measured by the buoy between $0000 \mathrm{UTC}, 14$ Oct. and 0000 UTC, 17 Oct. 2012. The blue solid line represents the SEVIRI $10.8 \mu \mathrm{m}$ brightness temperature (K) extracted at the location of the buoy. Hourly rainfall amount $\left(\mathrm{mm} \mathrm{h}^{-1}\right)$ observed by the rain gauge located at $12.5^{\circ} \mathrm{E}, 38^{\circ} \mathrm{N}$ are shown as grey bars. 

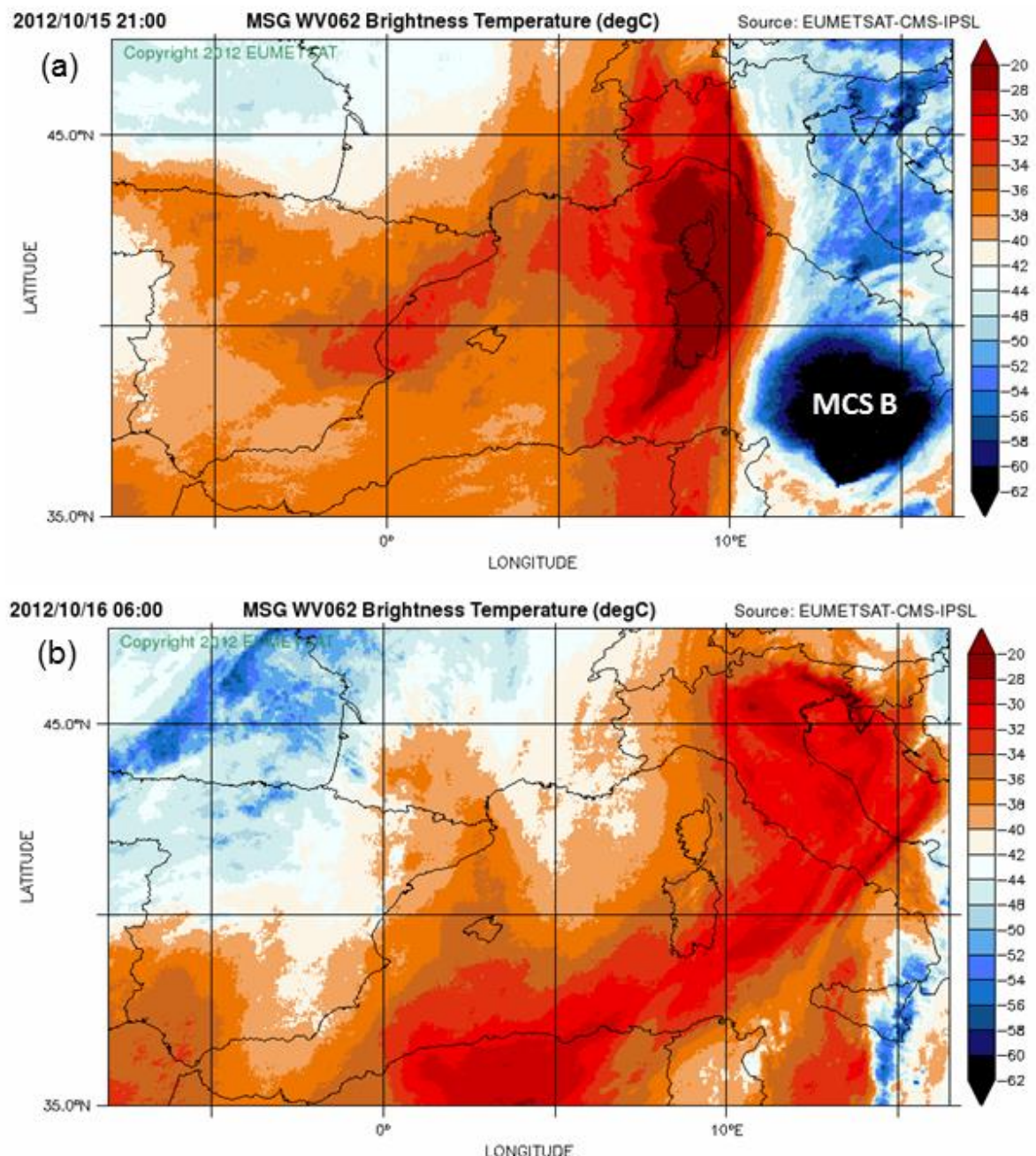

Figure 11. Distributions of brightness temperature at $6.2 \mu \mathrm{m}\left({ }^{\circ} \mathrm{C}\right)$ observed by SEVIRI (a) at $2100 \mathrm{UTC}, 15$ Oct. 2012, and (b) at 0600 UTC, 16 Oct. 2012. 
(a) TIWW (AROME, shade), TIWW (GPS, symbol)

\section{$\mathrm{Kg} / \mathrm{m}^{2}$}

(b) divergence $950 \mathrm{hPa}$ (shade), wind $10 \mathrm{~m}$
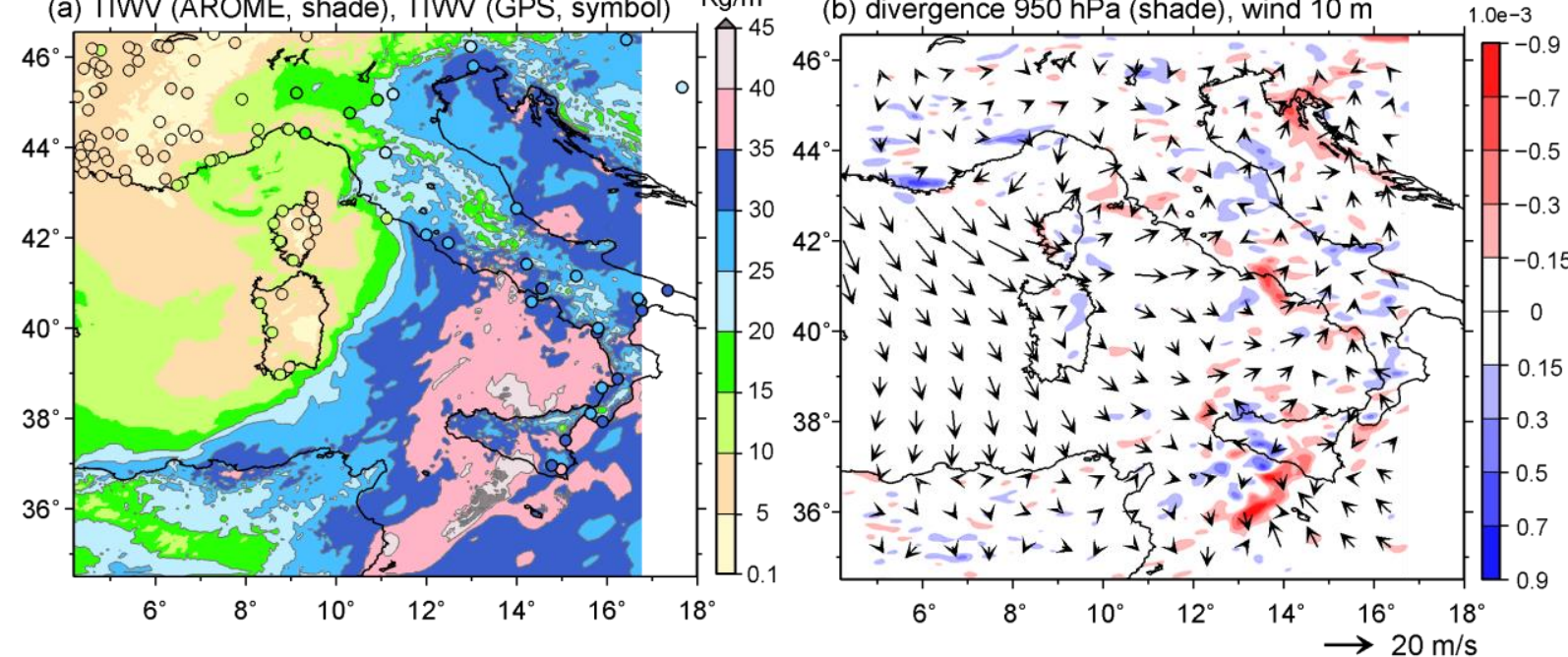

(c) Temp (shade); Obs (symbol), CAPE (contour)

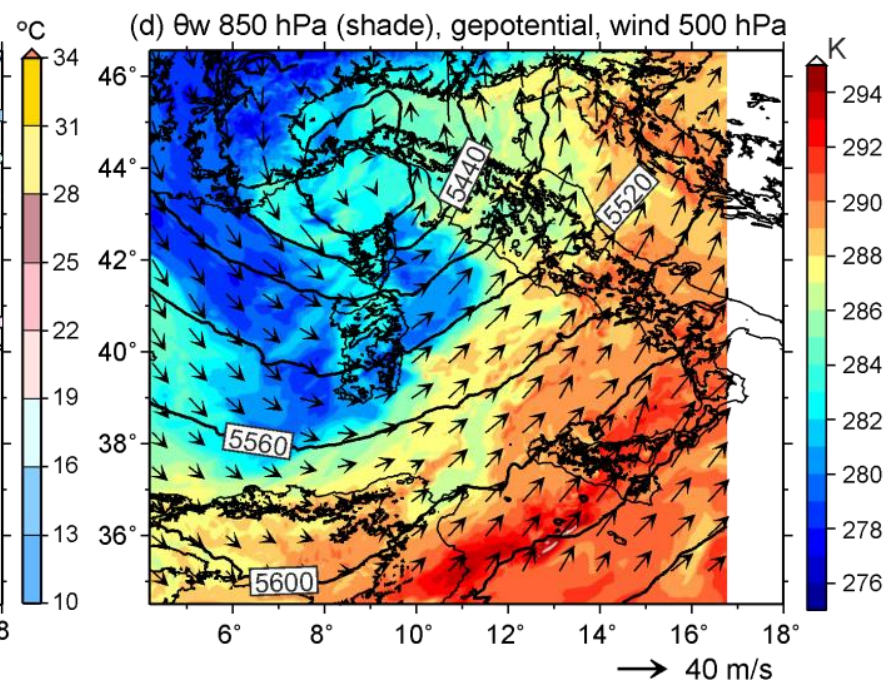

Figure 12. Same as Fig. 9 but for 2100 UTC, 15 Oct. 2012. 


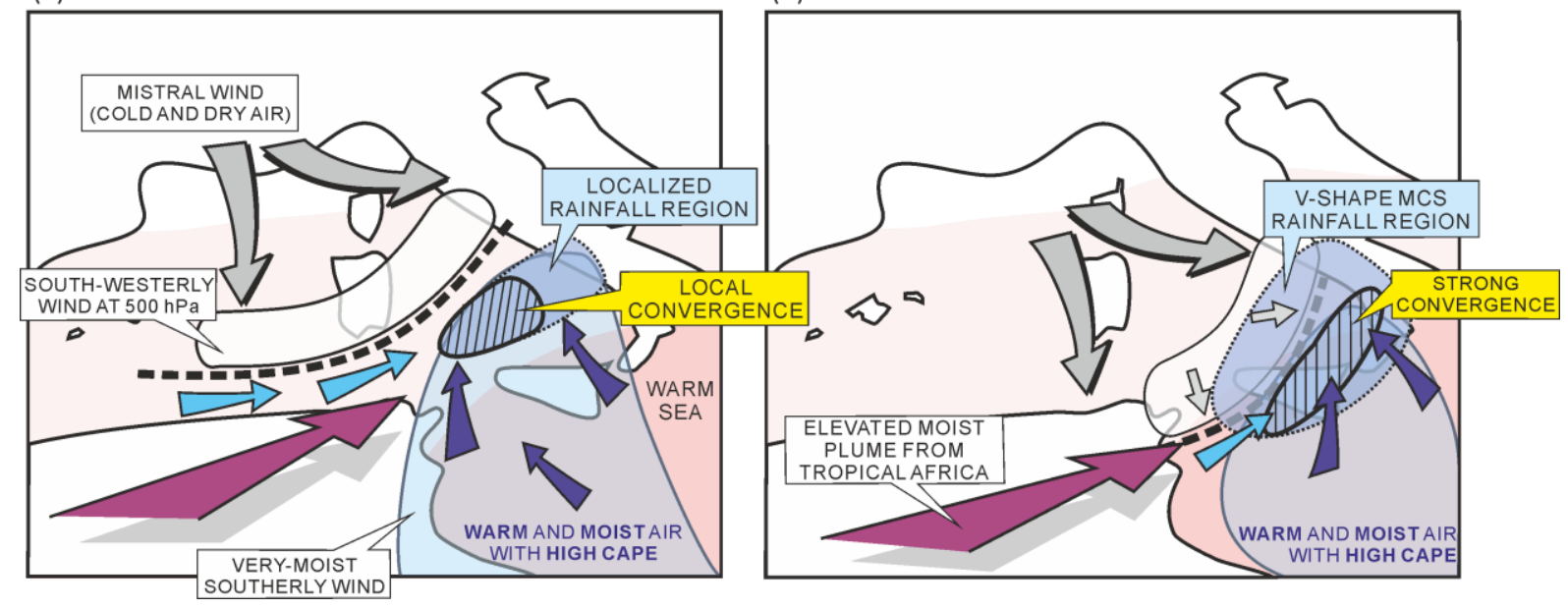

Figure 13. Schematics summarizing the main features and processes responsible for the maintenance of deep convection upstream of SI and leading to HPEs for Period 1 (a) and Period 2 (b). In (a) and (b), grey arrows indicate the mistral wind behind the edge of the cold front (thick dashed line). The light blue arrows depict the low-level westerlies to south-westerlies ahead of the front. Dark blue arrows show the low-level moist southerlies from the Eastern Mediterranean encompassed in the blue-shaded area. The purple arrow illustrates the elevated tropical plume. The local low-level convergence during P1 and the frontal shear during P2 are indicated by a hatched areas in (a) and (b), respectively. The rainfall regions are indicated by blueshaded encapsulated with the dotted line. 